\title{
Quaternary fluvial, pedogenic and mass-movement processes at St George's Down, Newport, Isle of Wight
}

3 Andrew R. Farrant ${ }^{1^{*}}$, Peter M. Hopson ${ }^{1}$, Jonathan R. Lee ${ }^{1}$, James B. Riding ${ }^{1}$ and 4 Richard N.L.B. Hubbard ${ }^{2}$

$5 \quad{ }^{1}$ British Geological Survey, Kingsley Dunham Centre, Keyworth, Nottingham NG12

$6 \quad 5 G G$, UK. Email arf@bgs.ac.uk

$7 \quad 230$ Hampstead Grove, London NW3 6SR, UK.

8 *Corresponding author. Email: arf@bgs.ac.uk

\section{Abstract}

Recent geological mapping on the Isle of Wight by the British Geological Survey has shown the 'Plateau Gravel' to be a mixture of fluvial, solifluction, pedogenic and marine deposits ranging from pre-Anglian to Holocene age. As part of the resurvey of the island, several new exposures of the 'Plateau Gravel' between Newport and Downend were examined. A working gravel pit on St George's Down, near Newport, revealed a succession of flint gravels with an inter-bedded sequence of laminated silts. An upper in situ succession of pre-Anglian fluvial gravels caps the plateau, but a second, probably younger suite of gravel-rich sediments is exposed in a quarry on a topographically lower spur. These overlie in situ Clay-with-flints resting on Upper Cretaceous Chalk. These lower sediments are well exposed and display a complex stratigraphy. They consist predominantly of flint gravel, but include a dipping succession of laminated silts and palaeosols preserved in a hollow or small channel feature, intercalated between two distinct soliflucted cold-stage gravel sheets. Palynological and pedological evidence analysis suggests that these laminated silts and sands were deposited under a temperate climate but with frequent episodes of disruption caused by mass-movement and possibly freeze-thaw. The age of these laminated sediments are not known with any certainty but are likely to date to a temperate interval within the Late Pleistocene. The top of the laminated unit is cut by a heavily cryoturbated horizon presumed to be of Devensian age.

Keywords: Isle of Wight, Quaternary, gravel, temperate, palaeosol, solifluction.

\section{Introduction}

Quaternary superficial deposits are important repositories of palaeoclimatic and palaeoevironmental information. The Hampshire - Isle of Wight region contains an extensive sequence of Quaternary river terraces and raised beaches associated with the development of the Solent River. During the Quaternary this was the largest river in southern England, but has now been truncated by sea-level rise (Everard, 1954). The terraces gravels on the northern side of the Solent River have been recognised for over a century and numerous lithostratigraphical schemes have been erected (see Allen and Gibbard (1993) for a comprehensive review). Many of these terrace and raised beach deposits are important archaeological sites; some, such as Boxgrove (Roberts and Parfitt, 1999) are of international significance. Although they have been extensively discussed in the literature the correlation and age of these deposits remain a subject of debate (Westaway et al., 2006; Briant et al., 2009). However, relatively little attention has been focused on the extensive Quaternary deposits that crop out on the on the 
southern side of the Solent river on the Isle of Wight. Most of these deposits were mapped as 'Plateau Gravel' during the primary geological surveys during the nineteenth century. However, the precise age, genesis and significance of these deposits as shown on the published geological maps (British Geological Survey, 1976) and memoirs (White, 1921) is poorly understood. It is unclear whether they represent shallow marine sediments, raised beaches, fluvial river terraces or solifluction sheets. Understanding the genesis and chronology of the 'Plateau Gravel' and placing its constituent parts into a robust chrono-stratigraphic framework will significantly improve the potential to interpret the archaeological record on the southern side of the Solent River. Recent remapping of the island by the British Geological Survey (BGS; in prep) demonstrates that the 'Plateau Gravel' are an amalgam of lithologically, temporally and genetically distinct deposits, and include Clay-with-Flints, periglacial solifluction deposits ('Head'), fluvial gravels, raised beaches and palaeosols. An understanding of the age and origin of these enigmatic deposits is critical to developing our knowledge of how the Isle of Wight fits into regional patterns of sea-level change, palaeoclimate and river system development within southern Britain, and contribute to the debate on the Quaternary uplift history of central southern England.

In this context, examining good sections through these deposits is critical. During the recent resurvey, a new section in the 'Plateau Gravel' was identified in the Bardon Vectis quarry on St George's Down near Newport (Figure 1). The quarry, active at the time of the survey, is located $1.5 \mathrm{~km}$ southeast of Newport, adjacent to the Shide Chalk pit [SZ506 881], but previous workings extended across much of the plateau between Shide and Arreton Cross [SZ530 867]. This paper describes the deposits seen in the present working quarry (2009-2010) and provides evidence for a multiphase, polygenetic origin for the 'Plateau Gravel'.

\section{History of research}

Although there has been a long history of geological investigation on the Isle of Wight, relatively little has been published on the extensive gravel and sand deposits (the 'Plateau Gravel') that occur widely across the central and northern parts of the island. These cap parts of the Chalk outcrop, form extensive spreads along the coast between Cowes and Ryde, where they are underlain by gently dipping Palaeogene strata, and also occur in association with the Medina River and Eastern Yar. The first geological survey, at the one-inch scale by H W Bristow, published in 1856 (British Geological Survey, 1856) only depicted the alluvium and blown sand as superficial deposits. The early memoirs from this time also make scant reference to the superficial deposits of the Chalk downs (Bristow, 1862; Forbes, 1856). The island was remapped at the six-inch-scale in 1886-87 (British Geological Survey, 1888) when the outcrops of Plateau Gravel shown on the 1976 1:50 000 reprinted map (British Geological Survey, 1976) were delimited. These were described in the short account of the geology of the Isle of White (White, 1921).

More recent mapping during 2006-2009 has shown that the 'Plateau Gravel' of the Isle of Wight is not a single entity but a combination of deposits at various levels and of various ages including Clay-with-flints, fluvial sands and gravels, palaeosols, solifluction deposits, and possible raised beaches, from which extensive drapes of younger soliflucted material emanate. At least two distinct gravel spreads can be identified across the island; a high level deposit at c 80-100 m OD capping the Chalk Downs between Newport and Downend (in part forming the St George's Down 
94 outcrop), and a more extensive, topographically lower, series of discontinuous sand and gravel outcrops along the northern coast of the Isle of Wight at around 45-50 m OD. Other more isolated outcrops occur elsewhere on the island.

However, despite numerous outcrops, there has been little published on these deposits apart from general discussions in Geological Survey memoirs and a limited number of papers together with several accounts in Quaternary Research Association field guides (Barber, 1987; Briant et al., 2009). These deposits are likely to be related to the evolution of the Solent River; see Allen and Gibbard, (1993) and references therein, Fookes (2008), Preece et al. (1990) and Velegrakis et al. (1999). Several authors (Bristow, 1862; Forbes, 1856; Reid and Strahan, 1889; White, 1921) have tried to divide the 'Plateau Gravel' deposits into groups on the basis of topographic elevation and geomorphological position, but with little success. Forbes (1856) subdivided the Plateau Gravel into three units but gives no description other than to identify them as 'superficial accumulations of later Tertiary age', and thus by implication of Pleistocene age. He also tried correlating the gravels with those of the River Stour in Dorset giving a clear implication that the Plateau Gravel deposits (at least in part) are remnants of Solent River terraces. Bristow (1862) maintained the tripartite division of the 'high level gravel', and for the first time gave a broad indication of the composition of the lower, northern gravels around Cowes as principally of "chalkflints and Tertiary pebbles, Upper Greensand cherts and materials from the LowerGreensand beds". However, any correlation with the Solent terraces on the mainland is likely to be erroneous as Codrington (1870) clearly states that "neither shells nor bones have been found in them [Plateau Gravel], though the valley-gravels have afforded mammalian remains in abundance". Codrington also differs from earlier authors in envisaging "a once continuous gravel-covered tableland" with a uniform slope to the north, as exemplified in his section 10 from St George's Down to Norris Castle [SZ 5148 9619], north of East Cowes. Reid and Strahan (1889) by contrast, state that the Plateau Gravel "do not seem to have belonged to one continuous sheet; for they occur at different levels" and thus by implication they therefore see the deposition of the Plateau Gravel as a series of stages. Hull (1912) uses the same evidence to assert a marine origin for the Plateau Gravel by whole-scale submergence. Thus only a quasi-correlation between the outcrops, and to those on the mainland, has been attempted in the past based on the relative height of the deposits and their presence (or not) of flint implements and faunal remains.

\section{St George's Down - site locality and context}

The St George's Down deposit is one of the highest gravel spreads on the island and forms a prominent topographical feature between Newport and Arreton (Figure 2) at the western end of the prominent Chalk ridge. Most of the deposit sits on a plateau at around 100-106 m OD, some $90 \mathrm{~m}$ above the floor of the present Medina valley, but slightly lower than the main Chalk ridge to the east. Smaller gravel-capped spurs occur at slightly lower elevations down to c. $80 \mathrm{~m}$ OD. The topographically highest deposit forms a strong landscape feature because the well-cemented ferruginous basal gravels have protected the underlying relatively soft Cretaceous strata (Greensand, 
142 gravel spreads is available in the literature. Reid and Strahan (1889) mention the St George's Down outcrop and describe over $9.1 \mathrm{~m}$ of rough stratified gravel composed almost entirely of flint (including a notable amount of rolled flints) with a few fragments of Upper Greensand chert and ironstone resting on an erosion surface at about $97.5 \mathrm{~m}$ OD. They noted that the abundance of cemented blocks is greatest along the southern margin of the deposit. White (1921) described an upper $2.44 \mathrm{~m}$ or so of 'structureless or confusedly banded gravel overlying well-stratified and currentbedded sand and gravel' with lenses and seams of grey stony 'loam'; this lower unit becoming more ferruginous downwards and fully cemented in the basal layers. He noted that the "gravel itself is of a brown colour, from the presence of iron, which frequently cements the fragments of flints together, and causes them to become consolidated into a hard flinty conglomerate."

154 The nature of the deposit and the gentle northwards slope of the mapped base led White to conclude a fluvial origin, deposited by a 'proto-Medina' presumably, as a right bank tributary of a Solent River. This account also describes the gravel flat of the Shide Golf Course (the area occupied by the currently active Bardon Vectis quarry) as being some $15 \mathrm{~m}$ below the main mass of the Down and considered as a later stage of this proto-Medina river. Everard (1954) also mentions the Shide Golf Course spur and the spur to the east that he attributed to his " $300-\mathrm{ft}$ Stage" (i.e. between 91.4 to $86.9 \mathrm{~m}$ ). The Shide Golf Course has now been relocated to make way for the present active quarry at [SZ 5075 8782], which is the location of the deposits described in this paper.

\section{Stratigraphy of the St George's Down deposits}

166

167

168

169

170

171

172

173

The St George's Down deposit can be divided into two major stratigraphic units, based largely on their topographical position. These are the main Upper Plateau gravels (UPG), now largely quarried away, and the slightly lower, more complex Shide Golf Course spur (SGC) deposits which were well exposed in the current Bardon Vectis quarry (Figure 3 and Table 1). Gravel also caps several other spurs at similar elevations around Great East Standen Farm. Solifluction deposits mantle the slope down into the Little Pan valley to the north.

In order to determine the age, palaeoenvironment and any palaeoclimatical signals in these sediments, a suite of samples were collected for clast lithological, palynological, micropalaeontological and micromorphological analyses. These are discussed below. The samples proved barren of ostracods and other micro-fauna, and no other fauna was found except reworked Cretaceous flint echinoids. Despite extensive searches in the past, no archaeological artefacts have been found in any of the exposures at St George's Down.

\subsection{Upper plateau deposits (UPG) at 100-106m OD}

Much of the higher part of the outcrop has long since been quarried away and few fragments remain available for study. White (1921) suggests that these Upper Plateau sediments could be subdivided into two units; a lower, often well cemented and stratified, fluvial cross-bedded ferruginous sand and gravel (UPG-1) which is probably in situ, overlain by an upper, possibly soliflucted deposit consisting of structureless or chaotically banded gravel (UPG-2). Several small outcrops of the lower stratified fluvial gravels (UPG-1a) occur along the southern margin of St 
189 stained, matrix-supported, crudely stratified and very poorly-sorted, well-cemented 190 gravel. The clasts consist predominantly of rolled, stained and rubified angular to subrounded, occasionally well-rounded brown flints up to $10 \mathrm{~cm}$ diameter with rare sandstone, ironstone and quartz in a ferruginous sandy matrix. The morphology of the flint clasts, coupled with poorly-sorted nature of the deposit and the style of bedding are indicative of sedimentation within a higher energy regime, probably fluviatile origin.

196 A small outcrop in a bunker on the new golf course [UPG-1b; SZ 5118 8723] revealed approximately one metre of the basal cross-bedded, coarse-grained, poorly-sorted sand and gravelly sand with rip up clasts of the underlying Gault Clay, resting on an undulating erosive surface cut into the bedrock (Figure $4 \mathrm{~b}$ ). These basal sands contain many small, well-rounded quartz pebbles. On the bridleway between Newport and Arreton (the Bembridge Trail) a small outcrop (UPG-1c) of cemented gravels is exposed at [SZ 5098 8709], close to the new Newport Golf Course Clubhouse. Approximately two metres of moderately well-cemented, coarse-grained, brown poorly-sorted flinty gravel can be seen. A similar small exposure lies behind the quarry plant area (UPG-1d) on an access road at [SZ 5154 8648], where a lower,

\subsection{Shide Golf Course (SGC) spur deposits (80-100 m OD)}

Workable deposits of gravel still exist at a slightly lower elevation adjacent to the Shide Chalk pit. This part of the quarry (Figure 5) underlies the old Shide Golf Course (since relocated to restored gravel workings on the upper plateau) and thus falls within the lower platform described in White (1921, p. 157). Aggregate reserve investigation maps (Hopkins, 1994), coupled with site visits and recent geological mapping (Figure 6) show that the gravel deposit here fills broad hollows within the Chalk bedrock and does not represent a uniform depositional sheet. The depth of the material is variable and ranges from a few metres of gravelly soil which does not form an aggregate resource, to around 15 metres of material with a distinct succession of gravely units.

Quarrying operations between 2007 and 2009 revealed a more complex stratigraphy in the central and eastern parts of this quarry, with a locally faulted and folded succession of flinty gravels, sands, and laminated, mottled silts at least $15 \mathrm{~m}$ thick (Figure 3). Continued quarrying in late 2008 showed that these laminated sands and silts, dipping towards the north, occupied a channel-fill or hollow within the thick flint gravel succession (Figure 7), and were overlain by yet more flint gravels, the base of which was marked by a well-developed cryoturbation surface. The laminated deposits were examined and sampled during the recent resurvey. The section in the main part of the quarry [SZ 5075 8782] can be divided into four main stratigraphical units.

\subsubsection{Basal unit (SGC-1)}

The base of the deposit rests on a very irregular, highly eroded and karstified surface developed on the underlying Seaford Chalk Formation, which here dips steeply to the northeast at $60^{\circ}$ to $70^{\circ}$. Deep dissolution pipes over $3 \mathrm{~m}$ deep have developed within the Chalk (Figure 8) and are infilled with very coarse-grained, sandy and clayey flint gravel, typically stained dark red or black by iron and manganese oxides. The margins of the pipes are often lined with stiff waxy dark orange-red clay, and may represent remnants of an earlier Clay-with-flints cover. Many of the flints in the lower part of the deposit are clearly derived from in situ weathering of the Seaford Chalk 
236 intact nodular and pipe flints. Rare silcrete sarsen stones, derived from Tertiary

237 regolith, also occur near the base of the deposit, some up to $1 \mathrm{~m}$ in diameter. A pocket

238 of very dark green to black glauconitic sand with disseminated calcareous material

239 was observed within the wall of one solution feature. This is presumed to be a

240 remnant of the original Palaeogene (Lambeth Group) cover.

241 4.2.2 Main gravel (SGC-2)

242 Most of the deposit observed is a structureless, coarse-grained, poorly-sorted flint 243 gravel set in matrix of very silty/clayey fine- to medium-grained sand (the lower 244 solifluction sheet shown in Figure 3). The flints are typically well-rolled, stained, 245 nodular, sub-rounded to subangular pebbles, with some Upper Greensand chert and 246 cherty siliceous sandstone clasts, and rare ironstone and ferruginous sandstone. This 247 unit is very variable in thickness, but typically exceeds $3 \mathrm{~m}$.

\section{$248 \quad 4.2 .3$ Laminated silts and sands (SGC-3)}

249 Within the central part of the quarry, a distinct unit of inclined silt, sand and gravel 250 occupies a hollow or channel several metres deep within the underlying Main Gravel 251 and clearly shows micro faulting, folding and convolutions. This is well exposed in a 252 section shown in Figure 7. The southern end of the section consists of fine- to coarse253 grained, poorly-sorted cobble gravels (part of the Main Gravel sequence, SGC-2) 254 255 made up of angular to sub-rounded flint with rare sandstone, ironstone and fine quartz pebbles in a sandy matrix, inter-bedded with silty clayey sand and very sandy clayey silt. A thicker unit within the Main Gravel comprising gravel, locally faulted and estimated to be around $6 \mathrm{~m}$ thick separates these lower sandy and silty gravels from a higher, distinctive unit of inclined laminated silts and sands (SGC-3).

The upper part of the channel succession is shown in detail in Figure 9. The base (Bed SGC-3A) consists of a steeply inclined and faulted unit of reddish-pink silty sandy clay with small angular flint pebbles and granules, with a slightly finer grained laminated sandy silt at its base. This is overlain by finely bedded to laminated greybrown-yellow-reddish pink, very fine-grained, sandy clayey silts (Bed SGC-3B). This is separated from the overlying bed by a slight erosional unconformity. Bed SGC-3C consists of very fine-grained, mottled and laminated reddish brown-pink sandy silt with rare rounded flint pebbles, and cross-cut by a network of pale grey pedogenic veining or rootlets, forming a distinctive palaeosol. At the top of this palaeosol there is a distinctive black to very dark greenish-grey, very fine-grained sandy silty clay layer, with much iron and manganese staining (Bed SGC-3D; the 'black band'). Above, Bed SGC-3E is a second succession of very fine-grained mottled and laminated reddish brown-pink sandy silt with pale grey pedogenic veining or rootlets. SGC-3F is a thin sandy horizon just below a thin pebble bed (Bed SGC-3G), overlain by a further succession of laminated pedogenic fine grained mottled silts (Bed SGC$3 \mathrm{H})$.

275 The top of this succession was exposed by subsequent quarrying in May 2009, and is 276 a heavily cryoturbated pale white or light brown fine grained silt or sandy silt with 277 angular flint pebble 'drop-stones' (SGC-3I; Figure 10) that appears to occupy the 278 centre of the channel or basin. The northern side of the channel/hollow was removed 279 by quarrying prior to the site survey and its overall morphology could not be 280 determined.

281 4.2.4 Upper gravel (SGC-4) 
The channel-fill succession is unconformably overlain by a sub-horizontal sheet of (angular to subangular bleached, rolled and shattered white flint clasts in a pale brown silty flinty matrix. The base of this deposit is marked by well-developed cryoturbation lobes that penetrate up to1.5 m into the underlying silts and sands (Figure 11) and the main gravel. This upper gravel rests directly upon the main gravel in much of the quarry and often cannot be distinguished from it where the cryoturbated horizon is not developed.

\subsubsection{Roadway section ( $S G C-4 b)$}

A second smaller section was exposed on the roadway into the main quarry (Figure 12) at [SZ 50758782]. Here, about $4.5 \mathrm{~m}$ of coarse-grained, poorly-sorted flint gravels are inter-bedded with pale grey mottled orange, very fine grained, sandy silty clay and finer flint gravels with orange, fine- to medium-grained and coarse-grained clayey matrix. These are inferred to be the lateral equivalent of the Upper Gravels.

\section{Gravel lithology and particle size}

To characterise these deposits, 18 bulk sediment samples were taken for particle size analysis and grading (Table 2). These were collected from the Upper Plateau deposits (UPG-1), the gravels within the current working quarry (SGC-2 and 4), the laminated silt and sand 'channel' deposits (SGC-3), and the roadway section (SGC-4b). Sand and gravel fractions determined by a combination of wet and dry and sieving (Gale and Hoare, 1991). Gravel residue from the particle size procedure was then graded using the methodology in British Standard 1377 from appropriately-sized samples taken from cleaned faces within the units. Quantitative counts were performed to determine clast shape and lithology. Identification of lithology was aided by the use of dilute hydrochloric acid and a binocular microscope.

Gravel is classified as being above $2 \mathrm{~mm}$ within the aggregate industry standard sieve sizes used in British Standard 1377. The 4-8 mm, 8-16 mm and 16-32 mm size ranges were isolated from the graded samples by secondary sieving, to accord with standard practice in Quaternary studies (Bridgland, 1986). Additional material in these ranges was washed from the unused split samples to provide a sample of sufficient size for clast lithological analysis.

The grading (Table 2) show that the gravel samples contain a lot of fines, with a maximum of $74.7 \%$ gravel clasts and a significant proportion of sand and silt. There appears to be little difference between the gravel samples. The laminated sand and silts are still relatively poorly-sorted with the exception of SGC-3B, C, D and H which are clean silts and clays.

Clast lithology analysis (Table 3) shows that the gravels are largely made up of reworked flint, accounting for $78 \%$ to $90 \%$ of the total. Despite examining over 17,000 clasts, no 'exotic' lithologies were identified except one large silcrete sarsen stone from the basal unit, which was probably derived from the former Palaeogene cover. All of the lithologies recorded within the gravel samples are derived from lithological units that crop out on the Isle of Wight.

The predominant component is flint derived from the Chalk Group which forms part of the bedrock beneath the St. George's Down as well as on the high ground in the south of the island. The majority of the flints are typically broken, rolled and stained, 
328 but in the basal gravel, relatively intact nodular, but heavily stained flints occur. In the 329 quarry, these are often mixed into a stiff orange-red waxy clay, and are typical of the 330 classic Clay-with-Flints deposits found elsewhere on the island. These are interpreted 331 to represent a remanié deposit derived from the original Palaeogene cover and it is 332 likely that this material was locally remobilised to fill solution hollows within the 333 underlying Chalk bedrock prior to the deposition of the main gravel deposit. Mixed in with the Clay-with-flints are large, less stained, intact fresh nodular and pipe flints that have weathered in situ out of the underlying Seaford Chalk Formation.

The chert, cherty sandstone and glauconitic sandstone were derived from the Upper Greensand Formation, which crops out to the south of the quarry and more extensively to the south of the island, whilst the well-rounded quartz fraction was probably derived from the Monk's Bay Sandstone Formation. The distribution of the quartz is highly variable; none was identified from the roadway upper section (SGC4b), but comprised over $18 \%$ of the Upper Plateau gravels (Sample PMH 4933, Plant Section UPG-1d, lower gravel). These were probably derived from the Monks Bay Sandstone Formation and indicate a very local source.

344 The results from the lithological analysis suggest that the St George's Down gravels were derived from a local proximal source, with no indication of any exotic material. The presence of material derived from the Upper Greensand Formation suggests a southerly origin, suggesting that the gravels represent the remains of a north-ward flowing, right bank tributary of the proto-Solent River.

Morphogenetic analysis indicates the gravels are dominated by angular and subangular clasts, which account for $49 \%$ and $47 \%$ respectively of total gravel sample with a much smaller $(2.16 \%)$ proportion of sub-rounded clasts. Several angular clasts were identified $(0.39 \%)$ but no rounded clasts. A small proportion of well-rounded clasts $(0.04 \%)$ probably represent reworked 'Tertiary' flint pebbles derived from the Palaeogene, either from pebble beds within the London Clay, or from subsequent fluvial mobilisation. No different morphological characteristics were identified between the upper and lower level gravel unit, suggesting that they were deposited under similar environmental conditions.

\section{Palynology}

Seven samples were collected from the laminated silts and palaeosols of the main 'channel' succession for palynological analysis. These were collected from fresh faces to maximise the palynomorph yield, and to minimise the potential for contamination by solitary bees and other burrowing organisms. The results of the palynological analyses are given in Table 3, with the key taxa presented as a summary pollen diagram (Fig. 13). The pollen assemblages are well-preserved and abundant; the slides contain thousands of grains. Exotic markers were not used hence the absolute concentrations cannot be precisely determined. They appear to be around 3000 grains $\mathrm{g}^{-1}$ on average, but the actual concentration may be significantly higher. The results are unusual, with a combination of unequivocal indicators of temperate conditions and exceptionally high non-arboreal (tree) pollen percentages with an absence of thermophilic tree types, followed by a rise in the impoverished arboreal pollen spectrum during which the thermophilous indicators disappear. 
375 The unusually low proportions of arboreal pollen in the majority of the samples may be partially due to an anomalous and parochial catchment. The rise in arboreal pollen, which virtually never includes any thermophilous taxa, is associated with a decline in Hedera pollen (indicative of temperate conditions) and appears to be contradictory. However, this is consistent with a change in catchment régime. The appearance of the pollen grains is sometimes unusual, with the pollen in the uppermost sample having a scorched appearance, as though caused by wildfire. The virtual absence of Gramineae (grass) pollen is also unusual.

The pollen preservation is variable throughout the succession. For example some of the Tubuliflorae (a subfamily of the Compositae) pollen have lost their spines, leaving an irregular coarse reticulation, making these specimens reminiscent of small Hedera grains. Some pollen grains exhibit an etched Hedera-like surface on one face, and perfect preservation on the other; this is caused by partial exposure from within the soil structure. Apart from establishing the identity of the more severely affected grains, these observations establish the primary fossil status of the Compositae pollen. Thus the pollen grains do not represent recent contamination. Similarly, the abundances of Compositae pollen herein do not represent transportation by digger bees (Bottema, 1975). It is clear that Compositae-rich floras such as these must have been a natural feature of some glacial settings, particularly where there was a suitable niche such as an irregular surface of bare soil.

The lower samples at St. George's Down, with their sparse tree/shrub pollen, the warmth-loving Hedera and rich herbaceous floras, are entirely consistent with an temperate, possibly interstadial event possibly around $200 \mathrm{~km}$ south of the icecap. The increase in arboreal pollen as the thermophile elements disappear would be expected when the climate reverted to extremely cold conditions. Here the disappearance of the local vegetation created an arctic desert in which long-distance transport of pollen becomes perceptible once local pollen production ceased. The paradoxical increase in arboreal pollen during periods of intense cold (and vice versa) has been documented by Gonzalez et al. (1966) and Eisner and Colinvaux (1990).

This interpretation of the St. George's Down palynology helps to rationalise many of the apparent anomalies. For example, on average $90 \%$ of the non-herbaceous pollen is restricted to Pinus (pine), Betula (birch), Alnus (alder), Salix (willow) and Juniperus (juniper) (Table 5). These taxa typify continental settings at the last interglacialglacial transition. The complete absence of Betula nana (dwarf birch) pollen, which may be present in glacial settings, is less surprising. Ligustrum (privet) has a similar distribution in Europe today to that of Hedera. These two plants frequently co-occur on alkaline screes along shorelines where the Hedera binds the rubble and the Ligustrum colonises it, despite wind and salt spray. Both have seeds which are distributed by birds, and are therefore capable of fairly rapid response to climatic amelioration. If the non-herbaceous pollen was reworked or residual, a source of older pollen higher up the chalky hillside would be indicated. The sparse ?Ulmus (elm) grains may be misidentifications of decayed or obscured specimens. However, the proportion of these anomalous types is distinctly higher in the uppermost two samples, where long-distance transport is fundamental to the general interpretation. The other anomalies are thought to be due to a parochial catchment, probably the top of an isolated spur of chalk downland and the local distribution of pollen by insectpollinated flowers. 
Palynological evidence from the later phases of the last glaciation in Britain is sparse. Comparable studies include the earlier, fully-temperate MIS 5a interstadial locality at Cassington described by Maddy et al. (1998) and the later interstadial deposits from the Ismaili Centre in west London documented by Gibbard (1985). The pollen spectra from St. George's Down and the Ismaili Centre differ greatly. This is due to the former being topographically high on an isolated block of chalk downland which probably had a very local catchment, and the latter site being on the Thames flood plain. The Ismaili Centre pollen analyses are more conventional in appearance, with $60-70 \%$ grass pollen, significant proportions of aquatic sedge pollen and low percentages of Artemisia (mugworts, sagebrush etc.), Chenopodiaceae (the goosefoot family) and tree pollen. Significantly, high percentages (ca. 20\%) of Liguliflorae (dandelions etc.) pollen were present; in normal interglacial deposits these types are present in lower proportions. This scenario is consistent with the site acquiring pollen from widespread areas to the north and west.

The main floral elements at St. George's Down are intergrowing Salix, Hedera and Ligustrum, and a carpet of miscellaneous representatives of the Compositae. One possibility is that the willow, ivy, and privet tangle occupied a sheltered hollow, perhaps on damp rubble, with the surrounding more exposed areas either being bare or carpeted with Composites. Alternatively, there may have been taller Composites growing in a damp hollows surrounded by patches of Salix, Hedera and Ligustrum dwarf thickets, lawn-like areas of low-growing Composites and bare soil. Later, there would have been nothing except bare soil with patches of low-growing Composites in the sheltered places.

The very unusual pollen diagram for the St George's Down site is not unique. Within the broader Solent River region, a similar pollen spectrum was reported from the River Avon terrace succession at Ibsley (Barber and Brown, 1987). The conclusions drawn from this site provides an environmental interpretation scenario that can be applied to the St George's Down site. The site at Ibsley produced a very unusual pollen diagram that is dominated by Ilex aquifolium (holly) and Hedera helix, in association with a great variety of herb pollen types dominated by the families Rosaceae, Umbelliferae and Rubiaceae. Crucially, in regard to a comparison with the St George's Down site, the Ibsley organic deposit also has exceptionally low tree pollen counts of Acer (maple/sycamore), Carpinus (hornbeam) and Picea (spruce), even lower counts of Fraxinus (ash), Pinus, Quercus (oak) and Fagus (beech) and rare grains of Graminae and Cyperaceae (sedges) with Alnus virtually absent. The interpretation of a tall herb-rich fen reverting to a drier fen with the evidence further suggesting regional deforestation. Both Hedera and Ilex are limited in their range by cold winters, and their habit as low pollen producers and poor dispersers demonstrate a high local population on impoverished soils.

Whilst beneath fluvial gravels of Devensian age, the interpretation of Barber and Brown (1987) favoured an Ipswichian interglacial age for the organic deposit, citing a regional high level of deforestation by large herbivores. These authors did, however, concede the possibility of a mid-Devensian (Upton Warren Interstadial) age, but this could not be substantiated by radiocarbon dating (interpreted by them from questionable data at $>43000$ years) and they further suggested that the interstadials of the Devensian were only marginally supportive of the thermophillous Hedera and Ilex. In summary, the pollen assemblages from St. George's Down reflect temperate conditions which are incompatible with full interglacial conditions due to the 
470

471

472

473

474

475

476

477

478

479

480

481

482

483

484

485

486

487

488

489

490

491

492

493

494

495

496

497

498

499

500

501

502

503

504

505

506

507

508

509

510

511

512

513

514

515

516

sparseness and character of the tree pollen. It is concluded that these findings could reflect either an interstadial or the early part of an interglacial.

\section{Soil micromorphology}

\subsection{Description of thin sections.}

Three thin section samples were also collected from the laminated silts and sands of the main channel succession for more detailed micro-morphological analysis (Figure 9). One was collected from the distinctive 'black band' (SGC-D) and the other two from above and below this horizon (SGC-E and B respectively). The samples were collected using kubiena tins $(8 \times 5 \times 4 \mathrm{~cm})$, air-dried before being impregnated with resin, and allowed to set prior to sectioning. The sections were described using standard pedological nomenclature (Kemp, 1985).

The basal sample (thin section 1) from the mottled silts (SGC-B) below the black band consists predominantly of silt with minor proportions of fine sand. The dominant constituent of the sand is quartz with minor plagioclase feldspar. Individual grains were typically subangular to subrounded in shape. Plasmic fabrics were developed throughout the section with randomly orientated silt particles (undifferentiated bfabrics) being especially common (Fig. 14a). Small (striated b-fabric) and large (strial b-fabric) zones of preferred clay and silt particle orientation were occasionally present. Voids are relatively common throughout the thin section although several appear to be the result of the thin section preparation. A number of channel structures were recorded cross-cutting some of the elongate fabrics indicating two different ages of channel clay coatings (Fig 14a).

The second sample (thin section 2) is from the 'black band' (SGC-D) and consists of heterogeneous sediment that can be broadly sub-divided into three zones: Zone 1 occurs within the basal third of the section and consists of weakly birefringent poorly sorted silty sand. Occasional fine silty laminae (up to $1.5 \mathrm{~mm}$ thick) were noted within this zone and are crossed by thin channel structures. These channels show a complex arrangement of clay coatings where three distinctive silt infills can be recognised on the basis of texture, birefringence and cross-cutting relationships. The second infill, characterised by highly birefringent clay can occasionally be observed as inclusions within the third clay coating. Zone 2 broadly encompasses the middle third of the thin section. It exhibits a marbled texture composed of intercalated horizons of clay-rich and clay-poor groundmass (Fig 14c). Well-developed striated and strial b fabrics are evident within the clay-poor areas of groundmass. Channel structures and associated clay infills are common. Four successive infills can be identified based upon texture, birefringence, extinction angle and cross-cutting relationships. The first three clay coating infills are large-scale and appear to occur throughout the zone and also show identical variations in texture, birefringence and geometry of the clay coatings to Zone 1. The second clay coating within Zone 2 contains rare inclusions of pre-existing fractured clay coatings (Fig 14b). The fourth undisturbed clay coating is highly localised in distribution and occurs within long, thin channels that cross-cut earlier clay coatings. Zone 3 broadly encompasses the upper third of the thin section and it consists of weakly stratified silty sand with moderately common striated b-fabrics. Several thin elongate channel structures are present and three distinctive clay coatings can be recognised. The first clay coating feature cross-cuts calcium carbonate depletion features. 
517 The third sample (thin section 3) was collected from the mottled silts overlying the 518 distinctive 'black band' (SGC-E). It consists of fine-medium sorted sand with a weakly developed undifferentiated b-fabric (Fig 14d). Some of the larger sand grains/granules exhibit tails of finer sand grains (galaxy structure) and are surrounded in highly birefringent silt and clay aligned parallel to the surface of the grain. A tail from one of these galaxy structures is truncated by a thin elongate channel which contains an undisturbed clay coating. The cross-cutting relationship of the micro-scale structural, textural and pedological features within these thin sections reveal a complex micro-stratigraphy shown in Table 5.

528

529

530

531

532

533

534

535

536

537

538

539

540

541

542

543

544

545

546

547

548

549

550

551

552

553

554

555

556 557

\section{8. Discussion}

559 The gravel deposits from St George's Down represent a complex history of

560 environmental change.

5618.1 Upper Plateau gravels (UPD-1 and 2)

The micro-scale pedological features provide valuable information regarding the palaeoenvironmental features from which they occurred (Kemp, 1985; Kemp et al., 1993; Rose et al., 2000). The carbonate depletion features in thin section 2 (the black band, SGC-D) indicate sediment decalcification in temperate/humid environments and tend to occur within the upper horizons of soils. Channels within the sediment are typically formed by earthworms or reflect root penetration, and provide an indication of temperate conditions. The coatings of these channels correspond to the downprofile translocation of clay under moist temperate climates. Fracturing of clay coatings often occurs in response to ground disruption as a result of freeze-thaw.

The thin sections from the laminated palaeosols at St George's Down indicate a long and complex pedological history. The succession consists of two soils separated by a mass-movement deposit (the black band, SGC-D). Within the lower palaeosol the presence of channel structures indicate the activity of earthworms and/or deep penetration of plant roots. This combined with six separate clay translocation features, plus the carbonate depletion features, suggests a background temperate climate. Two separate phases of soil disruption are evident from the thin sections and these are likely to correspond to short-term freeze-thaw events or slope instability. It is unclear whether these pedological features are seasonal or more long-term in nature. Several hiatuses are evident within the lower soil with the final hiatus being terminated by the deposition and remobilisation of sand that overlies the 'black band'. Stabilisation of this material is represented by the accretion of a palaeosol with the creation of microchannels by earthworm burrows and/or earthworms and subsequent clay translocation.

The micromorphological evidence is consistent with the palynological evidence which also indicates a temperate climate, with some intermittent colder phases, possibly related to seasonal changes in temperature. This temperate period must have pre-dated at least the last Devensian cold phase, as the upper part of the laminated succession is truncated by cold stage flint gravels with well-developed cryoturbation structures. Although a sample from the black band (SGC-3D, MPA58489) was taken for radiocarbon dating, the sample failed to produce sufficient carbon to date this horizon.

\subsection{Palaeoenvironmental interpretation}


562 The Upper Plateau deposits (at 100-105 m OD) have been largely quarried away, but the fragmentary remnants that remain, coupled with historical accounts suggest they were deposited by a northward-flowing fluvial system depositing material eroded from a local hinterland to the south. The coarse-grain size and poor sorting of the fluvial sand and gravel suggests they were deposited during a cold phase, and subsequently affected by solifluction and cryoturbation to produce the upper structureless gravels of White (1921).

Although no direct dating evidence is available for the St George's Down deposit, two independent lines of evidence suggest that they are probably pre-Anglian (Marine Isotope Stage 12) in age. The first is their topographic elevation. The gravel deposits are significantly higher than other fluvial terraces and raised beaches in the region. Several topographically lower, and thus younger gravel deposits have been identified within a $15 \mathrm{~km}$ radius of St George's Down which contain archaeological material and can thus be dated. The nearest are the lower terraces of the River Medina around Newport, the lowest of which occurs at c. 4-7 m OD, only 700 m north of the Bardon Vectis quarry. Roberts et al. (2006) demonstrated that at least two higher and earlier terraces are also present. At Great Pan Farm, these lower terraces contain prolific artefacts (Poole, 1924 ; Shackley, 1973, 1975; Wessex Archaeology, 1993). Finds include hand axes with distinctive bout coupé forms attributable to the British Mousterian, Levalloisian material and an elephant or mammoth molar. Organic material from the site has been dated to $>42,400 \mathrm{BP}$ using AMS radiocarbon dating (Roberts et al., 2006). Farther south, the 'Plateau Gravel' deposit that caps the Bleak Down ridge [SZ 516 816] has yielded numerous hand axes (Poole, 1934), often of a crude and heavily abraded nature, suggesting reworking or periglacial/fluvial transport. These fluvial gravels probably represent an early course of the River Medina at c. 75 m OD, but post-dating the St George's Down gravels based on topographical height criteria alone. Although there is no firm dating evidence, on purely geological grounds, based on the altitude of the terrace and the number and age of lower terraces preserved elsewhere, the Bleak Down terrace probably dates to during or shortly after the Anglian glaciation, or possibly earlier, and by inference the St George's Down Upper Plateau deposits must be older.

To the northeast of Newport, extensive sands and gravels have been mapped on the coast between Cowes and Bembridge at around 40-50 m OD. Although shown as Plateau/Marine gravel deposits on the 1976 geological map (British Geological Survey, 1976), their origin is more complex. These fluvial or marine sands and gravels are probably equivalent to the Marine Isotope Stage (MIS) 13 GoodwoodSlindon raised beach developed at c. 40 m OD. Similarly, the Steyne Wood Clay at Bembridge is also contemporary with the Goodwood-Slindon raised beach in Sussex, dated as c. 500,000 years BP immediately before the Anglian glaciation (Holyoak and Preece, 1983; Preece et al. 1990). The associated soliflucted gravel deposits at Priory Bay, near St Helens, which have yielded many artefacts have been dated by OSL to the post-Anglian Hoxnian/Wolstonian complex, between late MIS 11 to early MIS 9 (Wenban-Smith et al., 2009), although the veracity of the OSL dating is open to debate. However, this date is consistent with the deposit being a solifluction lobe derived from the main spread of Plateau/Marine gravels. At Bembridge, $15 \mathrm{~km}$ east of St George's Down, a younger Ipswichian (MIS 5e, c. 125,000 years BP) raised beach deposit is exposed on the coast (Preece et al., 1990; Wenban-Smith et al., 2005), overlain by substantial thicknesses of soliflucted sand and gravel of presumed Devensian age. These dates suggest that the in situ fluvial Upper Plateau deposits, 
611 which are present at a significantly higher altitude on St George's Down, are at least 612 pre-Anglian in age, and possibly much older, perhaps as old as the Early Pleistocene.

613 Secondly, numerous eoliths were reported by Poole (1939) from these gravels, but 614 these are now regarded as being naturally occurring rolled flints, rather than human artefacts. Given the long history of quarrying from this site, it seems likely that human artefacts do not occur in this deposit and thus the gravels date from a period before humans were present in this region.

\subsection{Shide Golf Course Spur deposits (SGC-1 to 4)}

619 The deposits on the lower spur adjacent to the Shide Chalk pit (and by association, on

620 the other spurs around Great East Standen farm) and are stratigraphically and topographically distinct from the Upper Plateau gravels and have a more complex stratigraphy. The lack of a definitive 'terrace' feature, coupled with the unstratified nature of the gravel and the highly irregular rock-head surface suggests the Shide Golf Course Spur is not a lower level terrace of the River Medina, but has a more complex multiphase origin. The basal deposit consists of pre-glacial Clay-with-flints that has been subsequently buried and affected by periglacial cryoturbation and solifluction. It has also undergone collapse and subsidence into dissolution pipes developed within the underlying Cretaceous Seaford Chalk Formation. The overlying main gravel succession represents a cold phase periglacial mass-movement event, probably derived from reworking of the gravel from the upper plateau by a combination of solifluction and fluvial mass movement. Dissolution of the underlying Chalk has continued throughout, and led to the generation of deep solution pipes into which the overlying gravel has subsided. Quarry workers have reported large cavities within the gravel, formed by suffosion of the gravel into dissolutional hollows which suggests that subsidence continued to affect the deposit. These suffosion sinkholes created small hollows which may periodically have been occupied by ponds into which the laminated sediments and palaeosols accreted. These sinkholes continued to evolve following deposition of the laminated silts and sands, leading to minor faulting and disruption of the overlying sediments. The laminated sediments were subsequently

640 buried by a second sheet of soliflucted gravel during the following cold phase.

641 Although attempts to date the laminated silts using radiocarbon techniques failed, it is 642 thought that the Shide Golf Course (SGD-1-4) sediments may span several coldtemperate phases. They are almost certainly younger than the Upper Plateau deposits from which they are derived. They represent a succession of soliflucted massmovement deposits that were emplaced over an existing Clay-with-flints deposit. The laminated silts were preserved in hollows generated by sinkhole development within this solifluction sheet, and subsequently buried by a second solifluction lobe. More recent valley incision and periglacial weathering has generated a second apron of solifluction deposits that mantle the slopes on the northern side of St George's Down.

650 The pollen and micromorphological data clearly indicate that the laminated silts 651 (SGC-3) were deposited under temperate conditions as a palaeosol, probably within a 652 subsidence hollow. However, the lack of tree pollen and indications of short-term 653 freeze-thaw events indicate that the climate was not sufficiently warm for full 654 interglacial conditions. Due to the truncation of the sequence by presumed Late 655 Devensian periglacial features and its lower elevation than the potentially pre-Anglian 656 higher-level gravels, it is considered that these deposits and soils were formed during 657 a late Middle to Late Pleistocene temperate interval. 
658 The St George's Down deposits clearly show that many of the deposits formerly 659 mapped as 'Plateau Gravel' are much more complex polyphase deposits than 660 previously realised. They include original in situ fluvial gravels (of possible pre661 Anglian age), Clay-with-flints, older periglacial solifluction deposits, temperate 662 sediments and younger periglacial solifluction sheets. It is clear that these later lobes 663 of soliflucted material are themselves polyphase deposits, developed over one or more 664 glacial-interglacial cycles.

665

666 667 668 669

\section{Conclusions}

The gravel deposits at St George's Down, formally mapped as 'Plateau Gravel', comprise a polygenetic sequence of fluvial, periglacial and temperate lacustrine sediments and palaeosols that formed over a long period of time. These deposits consist of topographically high-level in-situ fluvial gravels flanked by lobes of later cold-stage soliflucted material that are locally inter-bedded with temperate laminated silts and sands. On the Chalk outcrop, the soliflucted gravels overlie relict Clay-withflints deposits of probable Neogene or early Pleistocene age. The whole sequence is capped by more recent soliflucted and cryoturbated gravels. The composition of the St George's Down gravels, combined with their unrolled and unstained clast morphology, indicates that the gravels are locally derived and contain no exotic clasts indicative of a northern input. It is considered that they represent ancient fluvial deposits of the River Medina, which was a south-bank tributary of the Solent River system, that have subsequently been affected by several phases of cryoturbation, solifluction and subsidence, the latter due to sinkhole formation in the underlying Chalk. Laminated silts and clays record episodes of palaeosol and possible lacustrine sedimentation, with pollen indicating that in-part, the sequence was laid-down under a temperate climate. Micro-morphological analysis of palaeosols superimposed upon these laminated sediments suggest that they were situated close to a land-surface for long periods, with soil development occurring under a predominantly temperate climate (mild and wet) punctuated by disruption events that may be either the result of periglacial freeze-thaw or mass-movement.

The age of the sequence is difficult to determine with any certainty. The lack of human artefacts, coupled with its elevation and geomorphological position suggests the high-level in-situ fluvial gravels capping St George's Down are pre-Anglian in age and possibly as old as Early Pleistocene. However, the topographically lower soliflucted gravels and laminated silts on the Shide Golf Course spur are likely to be much younger. The palynology and micromorphology of the laminated silt and palaeosols indicate a temperate period, with its stratigraphic and geomorphological position relative to Devensian periglacial features and the higher-level gravels indicating a late Middle to Late Pleistocene age.

This site clearly shows that the 'Plateau Gravel' deposits on the Isle of Wight are more complex than hitherto thought. More detailed examination of these sediments is required to understand the evolution of south flank tributaries of the Solent River. Moreover, understanding the stratigraphic and chronological context of these sediments is crucial for interpreting the archaeological record in what is a major gateway for early human populations entering Britain. 
704 This work would not have been possible without the kind assistance of Stephen 705 Burton, the manager of Bardon Vectis Quarry. Chris Holden is thanked for his 706 assistance in the field in late 2009 and his work on the particle size analysis, clast 707 lithological and morphometric studies that he carried out as a work experience student 708 with BGS during 2009. This work formed part of his undergraduate dissertation at 709 Derby University in 2010. AF, PH, JL and JBR publish with the permission of the 710 Executive Director of the British Geological Survey (NERC).

\section{References}

713 Allen, L.G., Gibbard, P.L., 1993. Pleistocene evolution of the Solent River of 714 Southern England. Quaternary Science Reviews 12, 503-528.

715 Barber, K.E., 1987. Wessex and the Isle of Wight. Quaternary Research Association, 716 Cambridge.

717 Barber, K.E., Brown, A.G., 1987. Late Pleistocene organic deposits beneath the 718 floodplain of the River Avon at Ibsley, Hampshire. 65-74 in Barber, K.E. Editor, 719 Wessex and the Isle of Wight Field Guide, Quaternary Research Association, 720 Cambridge.

721 Bottema, S., 1975. The interpretation of pollen spectra from prehistoric settlements 722 (with special reference to Liguliflorae). Palaeohistoria 17, 17-35.

723 Briant, R.M., Hosfield, R.T., Wenban-Smith, F.F., 2009. The Quaternary of the Solent 724 Basin and West Sussex Raised Beaches. Quaternary Research Association, London.

725 Bridgland, D R., 1986. Clast lithological analysis. Technical Guide 3. Quaternary

726 Research Association, Cambridge, 207 pp.

727 Bristow, H.W., 1862. The geology of the Isle of Wight (Sheet 10). Memoir of the 728 Geological Survey of Great Britain and of the Museum of Practical Geology.

729 British Geological Survey, 1856. The Isle of Wight. One-inch Old Series, Special 730 sheet, England and Wales, Sheet 10 ed. British Geological Survey.

731 British Geological Survey, 1888. The Isle of Wight. One-inch New Series, Special 732 sheet, England and Wales. British Geological Survey.

733 British Geological Survey, 1976. The Isle of Wight 1:50,000 Special Sheet, England 734 and Wales. British Geological Survey, p. Geological map sheet. 
735 Codrington, T., 1870. On the superficial deposits of the south of Hampshire and the

736 Isle of Wight. Quarterly Journal of the Geological Society of London 26, 528-551.

737 Eisner, W.R., Colinvaux, P.A., 1990. A long pollen record from Ahaliorak Lake,

738 arctic Alaska. Review of Palaeobotany and Palynology 63, 35-52.

739 Everard, C.E., 1954. The Solent River: a geomorphological study. Transactions of the 740 Institute of British Geographers 20, 41-58.

741 Fookes, P., 2008. The Solent River Enigma. Geology Today 24, 8-9.

742 Forbes, E., 1856. On the Tertiary Fluvio-marine Formation of the Isle of Wight,

743 Memoir of the Geological Survey of Great Britain and of the Museum of Practical

744 Geology.

745 Gale, S.J., Hoare, P.J., 1991. Quaternary sediments: petrographic methods for the 746 study of unlithified rocks. Wiley, Chichester.

747 Gibbard, P.L., 1985. The Pleistocene history of the Middle Thames valley. Cambridge 748 University Press. 155 pp.

749 Gonzalez, E., van der Hammen, T., Flint, R.F., 1966. Late Quaternary glacial and 750 vegetational sequence in Valle de Lagunillas, Sierra Nevada del Cocuy, Colombia. 751 Leidische Geologische Mededelingen 32, 157-182.

752 Hopkins, D.A., 1994. Final geological and reserve appraisal of the Isle of Wight sand 753 and gravel sites. John Fyfe, Aberdeen.

754 Holyoak, D.T., Preece, R.C., 1983. Evidence of a high Middle Pleistocene sea-level 755 from estuarine deposits at Bembridge, Isle of Wight, England. Proceedings of the 756 Geologists' Association 94, 231-244.

757 Hull, E., 1912. On the interglacial gravel-beds of the Isle of Wight and the south of 758 England, and the conditions of their formation. Abstracts of the Proceedings of the 759 Geological Society of London, 913.

760 Kemp, R.A., 1985. Soil micromorphology and the Quaternary. Technical guide No. 2. 761 Quaternary Research Association.

762 Kemp, R.A., Whiteman, C.A., Rose, J., 1993. Palaeoenvironmental and stratigraphic 763 significance of the Valley Farm and Barham Soils in Eastern England. Quaternary 764 Science Reviews 12, 833-848. 
765 Maddy, D., Lewis, S.G., Scaife, R.G., Bowen, D.Q., Coope, G.R., Green, C.P.,

766 Hardaker, T., Keen, D.H., Rees-Jones, J., Parfitt, S., Scott, K., 1998. The upper

767 Pleistocene deposits at Cassington, near Oxford, England. Journal of Quaternary

768 Science 13, 205-301.

769 Poole, H.F., 1924 Palaeoliths from Great Pan Farm. Proceedings of the Hampshire 770 Field Club and Archaeological Society 9, 305-319.

771 Poole, H.F., 1934. Gravel and flint implements of Bleak Down. Proceedings of the 772 Hampshire Field Club and Archaeological Society 12, 20-47.

773 Poole, H.F., 1939. The Stone Age in the Isle of Wight. Proceedings of the Isle of 774 Wight Natural History and Archaeological Society 8, 33-47.

775 Preece, R.C., Scourse, J.D., Houghton, S.D., Knudsen, K.L., Penney, D.N., 1990. The 776 Pleistocene sea-level and neotectonic history of the Eastern Solent, Southern England.

777 Philosophical Transactions of the Royal Society of London B328, 425-477.

778 Reid, C., Strahan, A., 1889. The geology of the Isle of Wight (2nd Edition). Memoir 779 of the Geological Survey of England and Wales.

780 Roberts, M.B. and Parfitt, S.A., 1999. Boxgrove. A Middle Pleistocene hominid site 781 at Eartham Quarry, Boxgrove, West Sussex. London: English Heritage

782 Archaeological Report 17. 456pp

783 Roberts, M.B., Pope, M.I., Russell, K., 2006. The multidisciplinary investigation of 784 Middle to Late Pleistocene sediments and archaeological assemblages from Great Pan 785 Farm, Newport, Isle of Wight (SZ 5090 8872). Archaeology South East/University 786 College London.

787 Rose, J., Lee, J.R., Kemp, R.A., Harding, P.A., 2000. Palaeoclimate, sedimentation 788 and soil development during the last glacial stage (Devensian), Heathrow Airport, 789 London, UK. Quaternary Science Reviews 19, 827-847.

790 Shackley, M., 1973. A contextual study of the Mousterian industry from Great Pan 791 Farm, Newport, Isle of Wight. Proceedings of the Isle of Wight Natural History and 792 Archaeological Society 6, 542-554.

793 Shackley, M., 1975. A study of the Mousterian of Acheulian Tradition Industries of 794 Southern Britain. University of Southampton. 
795 Velegrakis, A.F., Dix, J.K., Collins, M.B., 1999. Late Quaternary evolution of the

796 upper reaches of the Solent River, Southern England, based upon marine geophysical

797 evidence. Journal of the Geological Society of London 156, 73-87.

798 Wenban-Smith, F.F., Bates, M.R., Bridgland, D.R., Marshall, G.D., Schwenniger, J.-

799 L., 2009. The Pleistocene sequence at Priory bay, Isle of Wight (SZ 635 900), In:

800 Briant, R.M., Hosfield, R.T., Wenban-Smith, F.F. (Eds.), The Quaternary of the

801 Solent Basin and West Sussex Raised Beaches, pp. 123-137.

802 Wenban-Smith, F.F., Schwenninger, J.-L., Scaife, R., 2005. New OSL dates and

803 pollen records from the Bembridge Raised Beach sequence, Isle of Wight (UK).

804 Quaternary Newsletter 107, 1-19.

805 Wessex Archaeology, 1993. The Southern Rivers Palaeolithic Project Report No.1, 806 1991-1992. The Upper Thames Valley, the Kennet Valley and the Solent Drainage 807 System. Wessex Archaeology.

808 Westaway, R., Bridgland, D. R., White, M. J., 2006. The Quaternary uplift history of 809 central southern England: evidence from the terraces of the Solent River system and 810 nearby raised beaches. Quaternary Science Reviews 25, 2212-2250.

811 White, H.J.O., 1921. A short account of the geology of the Isle of Wight. Memoir of 812 the Geological Survey of Great Britain (Reprint for 1994).

814 Captions

815 Figure 1. The St George's Down outcrop and its relationship to other outcrops of the 816 Plateau Gravel in the north-central part of the Isle of Wight. The terminology is based 817 on the British Geological Survey memoir (White, 1921).

818 Figure 2: Geological map of the St. George's Down area, based on published 819 geological survey (BGS 1976), showing the 'Plateau Gravel' outcrop, areas of gravel 820 extraction and bedrock geology.

821 Figure 3: Generalised stratigraphic section through the St George's Down deposits, 822 including the Shide Golf Course spur.

823 Figure 4a: One of the few remaining crags of the cemented gravel (Upper Plateau 824 Gravel - UPG-1a) seen on the southern margin of the St George's Down plateau. [SZ 8255100 8683]. Auger, 1.3m for scale. Photograph No P 692170, 10/10/07, ARF/NERC.

826 Figure 4b: Small exposure (UPG-1b) in a bunker on the relocated Newport Golf 827 Course [SZ 5118 8724] showing the basal cemented cross-bedded, ferruginous, 828 fluvial sands and gravels of the Upper Plateau Gravel resting on eroded Gault Clay 
829 bedrock. The contact is shown. The top and base of the section is talus. Photograph 830 No P 692164, 09/10/07, ARF/NERC.

831 Figure 5: Sketch of the workings in the active quarry on the Shide Golf Course Spur 832 (80-100 m OD), looking northwest.

833 Figure 6: Aggregate reserve investigation and geological map of the Shide Golf 834 Course Spur workings with the location of the sections mentioned in the text. UPG: St 835 George's Down Upper Plateau Gravels; SGC: soliflucted gravels on the Shide Golf 836 Course Spur.

837 Figure 7: Sketch section of the major exposure within the current workings on the 838 Shide Golf Course Spur.

839 Figure 8: Photograph of dissolution pipes developed in steeply dipping Seaford 840 Chalk, infilled with Clay-with-flints and soliflucted gravel.

841 Figure 9: Detailed section through the upper part of the laminated silts and sands 842 (SGC-3), showing beds and the location of thin section, pollen and micro843 palaeontological samples. $1.2 \mathrm{~m}$ soil auger for scale.

844 Figure 10: Photograph of the upper, heavily cryoturbated part of the laminated 845 channel sequence (SGC-3I) exposed by quarrying in May 2009.

846 Figure 11: Photo of the unconformable cryoturbated contact between the laminated 847 silts (SGC-3) and the overlying Upper Gravel (SGC-4) in the active workings. 848 Geological hammer for scale.

849 Figure 12: Sketch section of the roadway exposure within the current workings on the 850 Shide Golf Course Spur.

851 Figure 13: Summary pollen diagram for selected taxa/groups from St. George's

852 Down. The figures for Hedera are percentages of all pollen. All other calculations are 853 based on the pollen sum exclusive of Hedera. The dashed lines represent a x10 scale 854 expansion.

855 Figure 14: Soil thin section micrographs. (a) XPL view of thin section 1, located $85645 \mathrm{~cm}$ above the black band. The micrograph shows a poorly sorted, open framework 857 groundmass with moderately developed plasmic fabrics (alignments of silt and clay 858 particles) between grains, and vughs infilled by translocated clay. (b) XPL view of 859 thin section 2 , located $110 \mathrm{~cm}$ above the black band. The micrograph shows a poorly 860 sorted groundmass of sand with an open framework of interconnecting void space. 861 Through the centre of the micrograph is a clay lined void (rootlet structure). Note the 862 fragmented nature of the clay fill depicted by the differential birefringence of the 863 clays. (c) XPL view of thin section 2 , located $110 \mathrm{~cm}$ above the black band. A 864 distinctive feature of this zone within the micrograph is the marbled texture composed 865 of zones of clay-rich and clay-poor groundmass. Also evident are subtle alignments of 866 grains parallel to the surface of some of the larger clasts (see green arrows for 867 examples). Together, these features are interpreted as soft sediment mixing and grain 868 rotation within a mass-flow. (d) XPL view of thin section 3, located $220 \mathrm{~cm}$ above the 869 black band. Note the generally more sorted fine to medium sand grains which are 870 ubiquitous throughout the sample that characterise a low moderate energy 871 environment of deposition (i.e. waterlain). Soil processes are indicated by occasional 872 clay filled fractures (green arrow) which are the product of clay translocation. 
875 Table 1: Sedimentological characteristics and interpreted environment of deposition 876 of facies associations SGC-1 to 4 and UPG-1 to 2 at St George's Down, Isle of Wight, 877 England.

878 Table 2a. Bulk samples collected for particle size analysis from St George's Down, 879 both from the Upper Plateau Gravels (UPG) and from the active Shide Golf Course 880 workings (SGC-1 to 4). 2b. Proportions of particle sizes (weight \%) from St George's 881 Down. Samples SGC-3B to H are from the laminated silts.

882 Table 3: Clast lithology analysis.

883 Table 4. List of samples for pollen analysis from the laminated silts (SGC-3) with the 884 informal sample numbers, the BGS registration numbers (prefixed 'MPA'). The 885 quantitative data (pollen counts) for the seven samples studied. Three dashes (---) 886 indicates that the respective taxon was not represented

887 Table 5. Summary table showing the soil microstratigraphy from the three thin 888 section samples from St George's Down.

889

890 


\begin{tabular}{|c|c|c|c|c|c|}
\hline $\begin{array}{l}\text { Facies } \\
\text { Association }\end{array}$ & $\begin{array}{l}\text { Facies } \\
\text { Assemblage }\end{array}$ & Lower bounding surface & Geometry & Interpretation & $\begin{array}{l}\text { Depositional } \\
\text { Environment }\end{array}$ \\
\hline SGC-4 & $\mathrm{Gm}, \mathrm{Gcm}$ & Sharp cryoturbated surface & Massive poorly sorted gravel sheet & Solifluction lobe & $\begin{array}{l}\text { Cold phase solifluction } \\
\text { sheet on hill-slope }\end{array}$ \\
\hline SGC-3 & $\begin{array}{l}\text { Gm, Sh, Fl, Fr, } \\
\text { Fsc }\end{array}$ & $\begin{array}{l}\text { Sharp irregular surface, locally } \\
\text { faulted and steeply dipping }\end{array}$ & $\begin{array}{l}\text { Channel form with cryoturbation } \\
\text { and soft sediment deformation }\end{array}$ & $\begin{array}{l}\text { Palaeosol or } \\
\text { fluvio-lacustrine } \\
\text { low energy } \\
\text { deposition }\end{array}$ & $\begin{array}{l}\text { Temperate ?interstadial } \\
\text { channel or pond, possibly } \\
\text { developed within a } \\
\text { subsidence hollow }\end{array}$ \\
\hline SGC-2 & $\mathrm{Gm}, \mathrm{Gcm}$ & Gradational & Massive poorly sorted gravel sheet & Solifluction lobe & $\begin{array}{l}\text { Cold phase solifluction } \\
\text { sheet on hill-slope }\end{array}$ \\
\hline SGC-1 & $\mathrm{Gm}, \mathrm{Gcm}$ & $\begin{array}{l}\text { Highly irregular dissolutional surface } \\
\text { on Chalk bedrock }\end{array}$ & Deep pipes infilled with gravel & $\begin{array}{l}\text { Dissolution pipe } \\
\text { infill }\end{array}$ & $\begin{array}{l}\text { Subsidence of overlying } \\
\text { solifluction sheet into } \\
\text { Chalk dissolution pipe. }\end{array}$ \\
\hline UPG-2 & $\mathrm{Gm}$ & Not seen & Chaotic poorly bedded (not seen) & Solifluction lobe & $\begin{array}{l}\text { Cold phase solifluction } \\
\text { sheet? }\end{array}$ \\
\hline UPG-1 & $\mathrm{Gm}, \mathrm{Gp}, \mathrm{Ss}, \mathrm{Sl}$ & Erosional irregular, with planar & $\begin{array}{l}\text { Horizontally bedded gravel with } \\
\text { sand and silt scours }\end{array}$ & $\begin{array}{l}\text { Gravel bars and } \\
\text { sheet flood } \\
\text { deposits }\end{array}$ & $\begin{array}{l}\text { Shallow gravel-bed braided } \\
\text { river or alluvial fan. }\end{array}$ \\
\hline
\end{tabular}

Table 1. Sedimentological characteristics and interpreted environment of deposition of facies associations SGC-1 to 4 and UPG-1 to 2 at St George's Down, Isle of Wight, England. 


\begin{tabular}{|c|c|c|c|c|c|c|c|c|c|c|c|c|c|c|c|c|c|c|}
\hline $\begin{array}{c}\text { Locatio } \\
\text { n }\end{array}$ & $\begin{array}{c}\text { UPG } \\
-1 \\
\end{array}$ & $\begin{array}{c}\text { UPG- } \\
\text { 1d } \\
\text { (lower) }\end{array}$ & $\begin{array}{c}\text { UPG- } \\
1 d \\
\text { (upper } \\
\text { ) }\end{array}$ & $\begin{array}{c}\text { SGC- } \\
1\end{array}$ & $\begin{array}{c}\text { SGC- } \\
2\end{array}$ & $\begin{array}{c}\text { SGC- } \\
3 B\end{array}$ & $\begin{array}{c}\text { SGC- } \\
\text { 3B }\end{array}$ & $\begin{array}{c}\text { SGC- } \\
3 C\end{array}$ & $\begin{array}{c}\text { SGC- } \\
\text { 3D }\end{array}$ & $\begin{array}{c}\text { SGC- } \\
3 E\end{array}$ & $\begin{array}{c}\text { SGC- } \\
3 E\end{array}$ & $\begin{array}{c}\text { SGC- } \\
3 F\end{array}$ & $\begin{array}{c}\text { SGC- } \\
3 G\end{array}$ & $\begin{array}{c}\text { SGC- } \\
3 \mathrm{H}\end{array}$ & $\begin{array}{c}\text { SGC- } \\
4\end{array}$ & $\begin{array}{c}\text { SGC- } \\
4 b\end{array}$ & $\begin{array}{c}\text { SGC- } \\
4 b\end{array}$ & $\begin{array}{c}S G C \\
-4 b\end{array}$ \\
\hline Cobbles & 0 & 2.2 & 0 & 0 & 0 & 0 & 0 & 0 & 0 & 0 & 0 & 0 & 0 & 0 & 0 & 0 & 0 & 0 \\
\hline Gravel & 67 & 41.8 & 52.9 & 48.4 & 72 & 1.5 & 0.2 & 0 & 0.8 & 0.6 & 2.3 & 1.3 & 18.3 & 0.1 & 71 & 67.9 & 0.2 & 74.7 \\
\hline Sand & 12.7 & 34.3 & 42.9 & 18.9 & 9.4 & 15.6 & 15.9 & 4 & 5.6 & 28.4 & 16 & 17 & 19.5 & 13.8 & 10.6 & 17.7 & 20.3 & 6.3 \\
\hline Silt & 20.3 & 21.7 & 4.1 & 32.6 & 18.6 & 82.9 & 83.9 & 96 & 93.6 & 71 & 81.6 & 81.8 & 62.1 & 86.1 & 18.4 & 14.4 & 79.5 & 18.9 \\
\hline $\begin{array}{l}\text { Clay } \\
\text { Wet }\end{array}$ & 0 & 0 & 0 & 0 & 0 & 0 & 0 & 0 & 0 & 0 & 0 & 0 & 0 & 0 & 0 & 0 & 0 & 0 \\
\hline $\begin{array}{l}\text { weight } \\
\text { (g) }\end{array}$ & $\begin{array}{c}2230 \\
0 \\
\end{array}$ & 23050 & 30000 & $\begin{array}{c}2025 \\
0 \\
\end{array}$ & $\begin{array}{c}2910 \\
0\end{array}$ & $\begin{array}{c}1065 \\
0 \\
\end{array}$ & - & - & - & $\begin{array}{c}1250 \\
0 \\
\end{array}$ & - & - & - & - & $\begin{array}{c}2775 \\
0 \\
\end{array}$ & $\begin{array}{c}2155 \\
0 \\
\end{array}$ & 6500 & $\begin{array}{c}3020 \\
0 \\
\end{array}$ \\
\hline
\end{tabular}




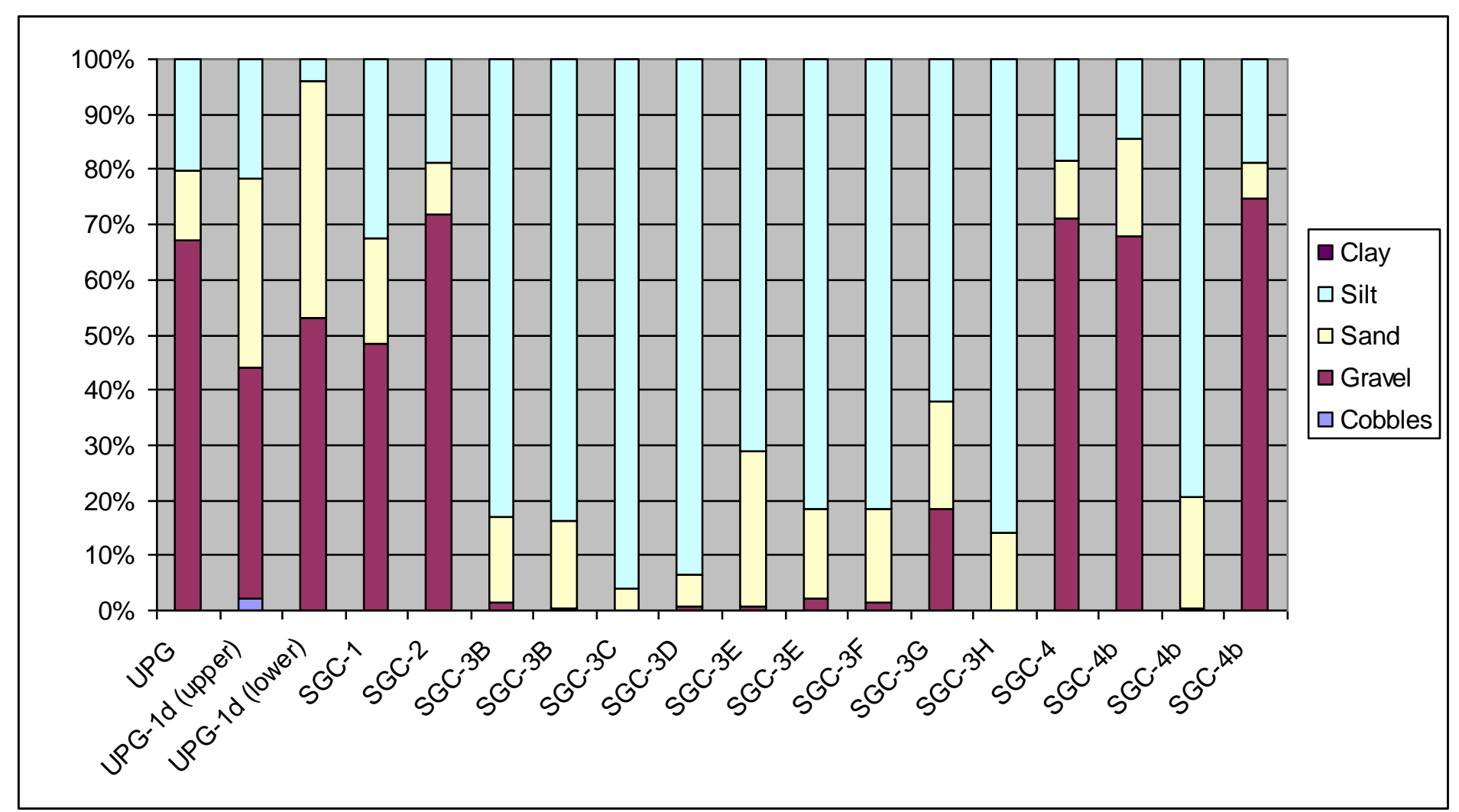

Table 2a. Bulk samples collected for particle size analysis from St George's Down, both from the Upper Plateau Gravels (UPG) and from the active Shide Golf Course workings (SGC-1 to4). 2b. Proportions of particle sizes (weight \%) from St George's Down. Samples SGC-3B to H are from the laminated silts. 


\begin{tabular}{|c|c|c|c|c|c|c|c|c|c|c|c|c|}
\hline Sample No & Sample Location & Size $(\mathrm{mm})$ & $\begin{array}{c}\text { Sample size } \\
\text { (n clasts) }\end{array}$ & $\begin{array}{c}\text { Fresh flints } \\
\text { (in situ Chalk) }\end{array}$ & $\begin{array}{l}\text { Reworked \& } \\
\text { rolled flints }\end{array}$ & $\begin{array}{c}\text { Stained } \\
\text { flints }\end{array}$ & $\begin{array}{c}\text { Sandstone } \\
\text { (Greensand) }\end{array}$ & $\begin{array}{c}\text { Chert } \\
\text { (Greensand) }\end{array}$ & $\begin{array}{c}\text { Cherty } \\
\text { Sandstone }\end{array}$ & $\begin{array}{c}\text { Seaford } \\
\text { Chalk }\end{array}$ & Quartz & $\begin{array}{c}\text { Sarsens } \\
\text { (Paleogene) }\end{array}$ \\
\hline Sample & Shide Golf Course Spur (SGC-1) & $32>16$ & 82 & 32 & 35 & 11 & 0 & 3 & 1 & 0 & 0 & 0 \\
\hline \multirow[t]{2}{*}{ PMH 4924} & Basal Unit Gravel (Chalk pinnacles) & $16>8$ & 214 & 64 & 97 & 26 & 2 & 7 & 5 & 0 & 10 & 3 \\
\hline & & $8>4$ & 1142 & 251 & 518 & 242 & 11 & 25 & 27 & 22 & 46 & 0 \\
\hline Sample & Shide Golf Course Spur (SGC-2) & $32>16$ & 310 & 0 & 288 & 0 & 5 & 4 & 12 & 0 & 0 & 0 \\
\hline \multirow[t]{2}{*}{ PMH 4925} & Main Gravel (below laminated silts) & $16>8$ & 696 & 0 & 636 & 0 & 28 & 7 & 30 & 0 & 0 & 0 \\
\hline & & $8>4$ & 3218 & 0 & 2891 & 0 & 249 & 19 & 49 & 0 & 10 & 0 \\
\hline Sample & Shide Golf Course Spur (SGC-4) & $32>16$ & 255 & 0 & 231 & 0 & 7 & 3 & 12 & 0 & 0 & 0 \\
\hline \multirow[t]{2}{*}{ PMH 4928} & Upper Gravel (above laminated silts) & $16>8$ & 620 & 0 & 558 & 0 & 37 & 9 & 16 & 0 & 0 & 0 \\
\hline & & $8>4$ & 2730 & 0 & 2482 & 0 & 158 & 29 & 55 & 0 & 6 & 0 \\
\hline Sample & Shide Golf Course Spur (SGC-4b) & $32>16$ & 208 & 0 & 169 & 0 & 19 & 6 & 14 & 0 & 0 & 0 \\
\hline \multirow[t]{2}{*}{ PMH 4929} & Roadway Section - Lower Gravel & $16>8$ & 594 & 0 & 538 & 0 & 31 & 11 & 18 & 0 & 0 & 0 \\
\hline & & $8>4$ & 2364 & 0 & 2119 & 0 & 196 & 18 & 30 & 0 & 1 & 0 \\
\hline Sample & Shide Golf Course Spur (SGC-4b) & $32>16$ & 157 & 0 & 133 & 0 & 7 & 9 & 8 & 0 & 0 & 0 \\
\hline \multirow[t]{2}{*}{ PMH 4931} & Roadway Section - Upper Gravel & $16>8$ & 237 & 0 & 219 & 0 & 12 & 2 & 4 & 0 & 0 & 0 \\
\hline & & $8>4$ & 955 & 0 & 843 & 0 & 99 & 6 & 7 & 0 & 0 & 0 \\
\hline Sample & Upper Plateau Gravel (UPG-1) & $32>16$ & 236 & 0 & 200 & 0 & 26 & 6 & 4 & 0 & 0 & 0 \\
\hline \multirow[t]{2}{*}{ PMH 4932} & Bridleway section & $16>8$ & 409 & 0 & 352 & 0 & 44 & 6 & 7 & 0 & 0 & 0 \\
\hline & [SZ 5098 8709] & $8>4$ & 998 & 0 & 914 & 0 & 43 & 9 & 30 & 0 & 2 & 0 \\
\hline Sample & Upper Plateau Gravel (UPG-1) & $32>16$ & 123 & 0 & 108 & 0 & 7 & 5 & 3 & 0 & 0 & 0 \\
\hline \multirow[t]{2}{*}{ PMH 4933} & Plant Section Lower Gravel & $16>8$ & 277 & 0 & 252 & 0 & 6 & 5 & 14 & 0 & 0 & 0 \\
\hline & [SZ 5154 8648] & $8>4$ & 1325 & 0 & 1036 & 0 & 65 & 100 & 23 & 0 & 101 & 0 \\
\hline Sample & Upper Plateau Gravel (UPG-1) & $32>16$ & 137 & 0 & 121 & 0 & 4 & 8 & 4 & 0 & 0 & 0 \\
\hline \multirow[t]{2}{*}{ PMH 4934} & Plant Section Upper Gravel & $16>8$ & 274 & 0 & 256 & 0 & 4 & 0 & 3 & 0 & 11 & 0 \\
\hline & [SZ 5154 8648] & $8>4$ & 1226 & 0 & 921 & 0 & 26 & 3 & 15 & 0 & 261 & 0 \\
\hline Sample & Shide Golf Course Spur (SGC-2) & $32>16$ & 260 & 0 & 228 & 0 & 23 & 5 & 4 & 0 & 0 & 0 \\
\hline
\end{tabular}




\begin{tabular}{|c|c|c|c|c|c|c|c|c|c|c|c|c|}
\hline PMH 4935 & Main Gravel (> $8 \mathrm{~mm}$ fraction) & $\begin{array}{c}16>8 \\
8>4\end{array}$ & $\begin{array}{l}1684 \\
\mathrm{~N} / \mathrm{A} \\
\end{array}$ & $\begin{array}{c}0 \\
\mathrm{~N} / \mathrm{A}\end{array}$ & $\begin{array}{l}1521 \\
\mathrm{~N} / \mathrm{A} \\
\end{array}$ & $\begin{array}{c}0 \\
\mathrm{~N} / \mathrm{A}\end{array}$ & $\begin{array}{l}131 \\
\mathrm{~N} / \mathrm{A}\end{array}$ & $\begin{array}{r}15 \\
\mathrm{~N} / \mathrm{A}\end{array}$ & $\begin{array}{c}16 \\
\mathrm{~N} / \mathrm{A}\end{array}$ & $\begin{array}{c}0 \\
\text { N/A }\end{array}$ & $\begin{array}{c}1 \\
\mathrm{~N} / \mathrm{A}\end{array}$ & $\begin{array}{c}0 \\
\mathrm{~N} / \mathrm{A}\end{array}$ \\
\hline Sample & Shide Golf Course Spur (SGC-4) & $32>16$ & 162 & 0 & 152 & 0 & 7 & 0 & 3 & 0 & 0 & 0 \\
\hline PMH 4937 & Upper Gravel (> 8 mm fraction) & $16>8$ & 1087 & 0 & 989 & 0 & 65 & 16 & 17 & 0 & 0 & 0 \\
\hline & & $8>4$ & $N / A$ & $N / A$ & $\mathrm{~N} / \mathrm{A}$ & $N / A$ & $\mathrm{~N} / \mathrm{A}$ & $\mathrm{N} / \mathrm{A}$ & $N / A$ & N/A & $N / A$ & N/A \\
\hline
\end{tabular}

Table 3. Clast Lithology analysis. 


\begin{tabular}{|c|c|c|c|c|c|c|c|}
\hline \multirow{3}{*}{$\begin{array}{l}\text { Shide Golf Course } \\
\text { Spur - Laminated silts } \\
\text { (Channel fill) }\end{array}$} & Sample Number & $\begin{array}{c}\text { MPA } \\
58485\end{array}$ & $\begin{array}{c}\text { MPA } \\
58486\end{array}$ & $\begin{array}{l}\text { MPA } \\
58487\end{array}$ & $\begin{array}{c}\text { MPA } \\
58488\end{array}$ & $\begin{array}{c}\text { MPA } \\
58489\end{array}$ & $\begin{array}{c}\text { MPA } \\
58490\end{array}$ \\
\hline & Location & $\begin{array}{c}\text { SGC3 } \\
-\mathrm{H}\end{array}$ & $\begin{array}{l}\text { SGC3 } \\
-G\end{array}$ & $\begin{array}{c}\text { SGC3 } \\
-\mathrm{F}\end{array}$ & $\begin{array}{l}\text { SGC3 } \\
-E\end{array}$ & $\begin{array}{l}\text { SGC3 } \\
-D\end{array}$ & $\begin{array}{l}\text { SGC3 } \\
-\mathrm{C}\end{array}$ \\
\hline & BGS registration No & $\begin{array}{c}\text { MPA } \\
58485\end{array}$ & $\begin{array}{r}\text { MPA } \\
58486\end{array}$ & $\begin{array}{r}\text { MPA } \\
58487\end{array}$ & $\begin{array}{c}\text { MPA } \\
58488\end{array}$ & $\begin{array}{c}\text { MPA } \\
58489\end{array}$ & $\begin{array}{r}\text { MPA } \\
58490\end{array}$ \\
\hline POLLEN TYPE & COMMON NAME & & & & & & \\
\hline \multicolumn{8}{|l|}{ Trees } \\
\hline Pinus & Pine & 4 & 2 & --- & --- & --- & 5 \\
\hline Betula & Birch & 17 & 10 & 7 & --- & 8 & 5 \\
\hline Alnus & Alder & 25 & 88 & 35 & 6 & 17 & 19 \\
\hline ?Ulmus & Elm & 6 & 9 & 2 & --- & 1 & 3 \\
\hline Acer & Maple & --- & 2 & --- & --- & --- & --- \\
\hline \multicolumn{8}{|l|}{ Shrubs } \\
\hline Corylus & Hazel & 9 & 25 & --- & --- & 3 & $\begin{array}{ll}-- \\
\end{array}$ \\
\hline Salix & Willow & 3 & 15 & 22 & 19 & 3 & 12 \\
\hline Juniperus & Juniper & 1 & 7 & --- & --- & --- & --- \\
\hline Ligustrum & Privet & --- & 1 & 3 & --- & --- & --- \\
\hline Hedera & Ivy & --- & 74 & 118 & 160 & 145 & 1 \\
\hline \multicolumn{8}{|l|}{ Grasses } \\
\hline Gramineae & Grasses & 7 & 25 & 10 & 3 & 6 & 7 \\
\hline \multicolumn{8}{|l|}{ Open ground herbs } \\
\hline Chenopodiaceae & Chenopods/Goosefoot & --- & --- & 3 & --- & --- & --- \\
\hline Plantago lanceolata & Ribwort plantain & 4 & 1 & --- & --- & --- & --- \\
\hline Plantago major/media & Greater/Hoary plantains & 2 & --- & --- & --- & --- & --- \\
\hline Rumex acetosa & Common sorrel & 3 & --- & --- & --- & --- & --- \\
\hline \multicolumn{8}{|l|}{ Herbs - miscellaneous } \\
\hline Caryophyllaceae & Carnations/Pinks & & & & & & \\
\hline Sagina-type & Pearlwort & --- & --- & --- & --- & --- & 4 \\
\hline Convolvulus & Bindweed & --- & --- & 1 & 1 & --- & 2 \\
\hline \multicolumn{8}{|l|}{$\begin{array}{c}\text { Asteraceae } \\
\text { (Compositae) }\end{array}$} \\
\hline $\begin{array}{c}\text { Cichorioideae } \\
\text { (Liguliflorae) }\end{array}$ & Dandelions & & & & & & \\
\hline small & & --- & --- & 5 & 186 & 3 & 16 \\
\hline medium sized & & $\begin{array}{ll}-- \\
\end{array}$ & --- & 93 & 176 & 7 & 10 \\
\hline $\begin{array}{c}\text { Asteriodeae } \\
\text { (Tubuliflorae) }\end{array}$ & Daisys/Thistles & & & & & & \\
\hline Arcticum-type & Burdock & --- & --- & 2 & 3 & --- & --- \\
\hline small & Daisey-type & --- & 20 & 296 & 120 & 199 & 468 \\
\hline medium sized & Hemp-Agrimony-type & --- & 5 & 9 & 2 & 62 & 25 \\
\hline large & Thistle-type & $\begin{array}{ll}-- \\
\end{array}$ & 5 & 13 & $\begin{array}{c}-- \\
\end{array}$ & 13 & 5 \\
\hline Filipendula-type & Meadowsweet & 2 & 6 & 43 & 10 & 12 & 17 \\
\hline Leguminosae & Peas & & & & & & \\
\hline
\end{tabular}




\begin{tabular}{|c|c|c|c|c|c|c|c|}
\hline Anthyllis-type & Kidney vetch & --- & 83 & --- & --- & --- & --- \\
\hline Liliaceae & Lilies & & & & & & \\
\hline Allium-type & Field garlic & --- & --- & --- & --- & --- & 1 \\
\hline Mercurialis-type & Dog's mercury & --- & --- & --- & --- & --- & 1 \\
\hline Urtica & Nettle & 3 & 1 & $\begin{array}{ll}-- \\
\end{array}$ & $\begin{array}{ll}-- \\
\end{array}$ & 4 & --- \\
\hline Ranunculus & Buttercup & --- & 105 & 1 & 2 & 5 & 6 \\
\hline \multicolumn{8}{|l|}{ Heath } \\
\hline Calluna & Heather/Ling & --- & 3 & --- & --- & --- & --- \\
\hline \multicolumn{8}{|l|}{ SPORE TYPE } \\
\hline \multicolumn{8}{|l|}{ Ferns/clubmosses } \\
\hline Dryopteris-type & Buckler or Wood fern & 2 & 1 & --- & 1 & 2 & 6 \\
\hline Polypodium & Ferns (undifferentiated) & --- & 2 & --- & --- & --- & 1 \\
\hline Pteridium & Bracken & 1 & 9 & --- & --- & --- & --- \\
\hline Lycopodium & Clubmoss & --- & --- & --- & --- & --- & 4 \\
\hline
\end{tabular}

Table 4. List of samples for pollen analysis from the laminated silts (SGC-3) with the informal sample numbers, the BGS registration numbers (prefixed 'MPA'). The quantitative data (pollen counts) for the seven samples studied. Three dashes (---) indicates that the respective taxon was not represented 


\begin{tabular}{|c|c|c|c|c|c|}
\hline $\begin{array}{l}\text { Soil Micro- } \\
\text { stratigraphy }\end{array}$ & Bed & $\begin{array}{c}\text { Thin } \\
\text { Section }\end{array}$ & Micromorphological Evidence & Interpretation & $\begin{array}{l}\text { Palaeo- } \\
\text { environm }\end{array}$ \\
\hline $\mathrm{O}$ & SGC-3E & 3 & $\begin{array}{l}\text { Channels, clay translocation features } \\
\text { and clay coatings }\end{array}$ & Soil accretion & Temperat \\
\hline $\mathrm{N}$ & SGC-3E & 3 & $\begin{array}{l}\text { Sand deposition, grain coatings and } \\
\text { galaxy structures }\end{array}$ & $\begin{array}{l}\text { Low energy sedimentation } \\
\text { followed by downslope } \\
\text { remobilisation }\end{array}$ & Fluvial \\
\hline $\mathrm{M}$ & SGC-3D & 2 & Unconformity & Erosion or non-deposition & \\
\hline $\mathrm{L}$ & SGC-3D & 2 & $\begin{array}{l}\text { Channels, clay translocation and } \\
\text { accretion of clay coatings (Zone } 2 \text { ) }\end{array}$ & Soil accretion & Temperat \\
\hline $\mathrm{K}$ & SGC-3D & 2 & Carbonate depletion structures & Sediment decalcification & $\begin{array}{l}\text { Temperat } \\
\text { humid }\end{array}$ \\
\hline $\mathrm{J}$ & SGC-3D & 2 & Unconformity & Erosion of non-deposition & \\
\hline I & SGC-3D & 2 & $\begin{array}{l}\text { Clay translocation and accretion of } \\
\text { clay coatings (Zones } 1 \text { and } 2 \text { ) }\end{array}$ & Soil accretion & Temperat \\
\hline $\mathrm{H}$ & SGC-3D & 2 & Fracturing of clay coatings (Zone 1) & Soil disruption & $\begin{array}{l}\text { Cold / ma } \\
\text { movemen }\end{array}$ \\
\hline G & SGC-3D & 2 & $\begin{array}{l}\text { Clay translocation and accretion of } \\
\text { clay coatings (Zones } 1 \text { and } 2 \text { ) }\end{array}$ & Soil accretion & Temperat \\
\hline $\mathrm{F}$ & SGC-3D & 2 & Fracturing of clay coatings (Zone 2) & Soil disruption & $\begin{array}{l}\text { Cold / ma } \\
\text { movemen }\end{array}$ \\
\hline $\mathrm{E}$ & SGC-3D & 2 & $\begin{array}{l}\text { Channels, clay translocation features } \\
\text { and clay coatings in (Zones } 1 \text { and } 2 \text { ) }\end{array}$ & Soil accretion & Temperat \\
\hline $\mathrm{D}$ & SGC-3D & 2 & $\begin{array}{l}\text { Unconformity, deposition of 'Black } \\
\text { Sand' }\end{array}$ & & \\
\hline $\mathrm{C}$ & SGC-3B & 1 & $\begin{array}{l}\text { Clay translocation and accretion of } \\
\text { clay coatings }\end{array}$ & Soil accretion & Temperat \\
\hline B & SGC-3B & 1 & $\begin{array}{l}\text { Channels, clay translocation features } \\
\text { and clay coatings }\end{array}$ & Soil accretion & Temperat \\
\hline $\mathrm{A}$ & SGC-3B & 1 & $\begin{array}{l}\text { Formation of groundmass soil } \\
\text { plasmic fabrics. }\end{array}$ & & \\
\hline
\end{tabular}

Table 5. Summary table showing the soil microstratigraphy from the three thin section samples from St George's Down. 


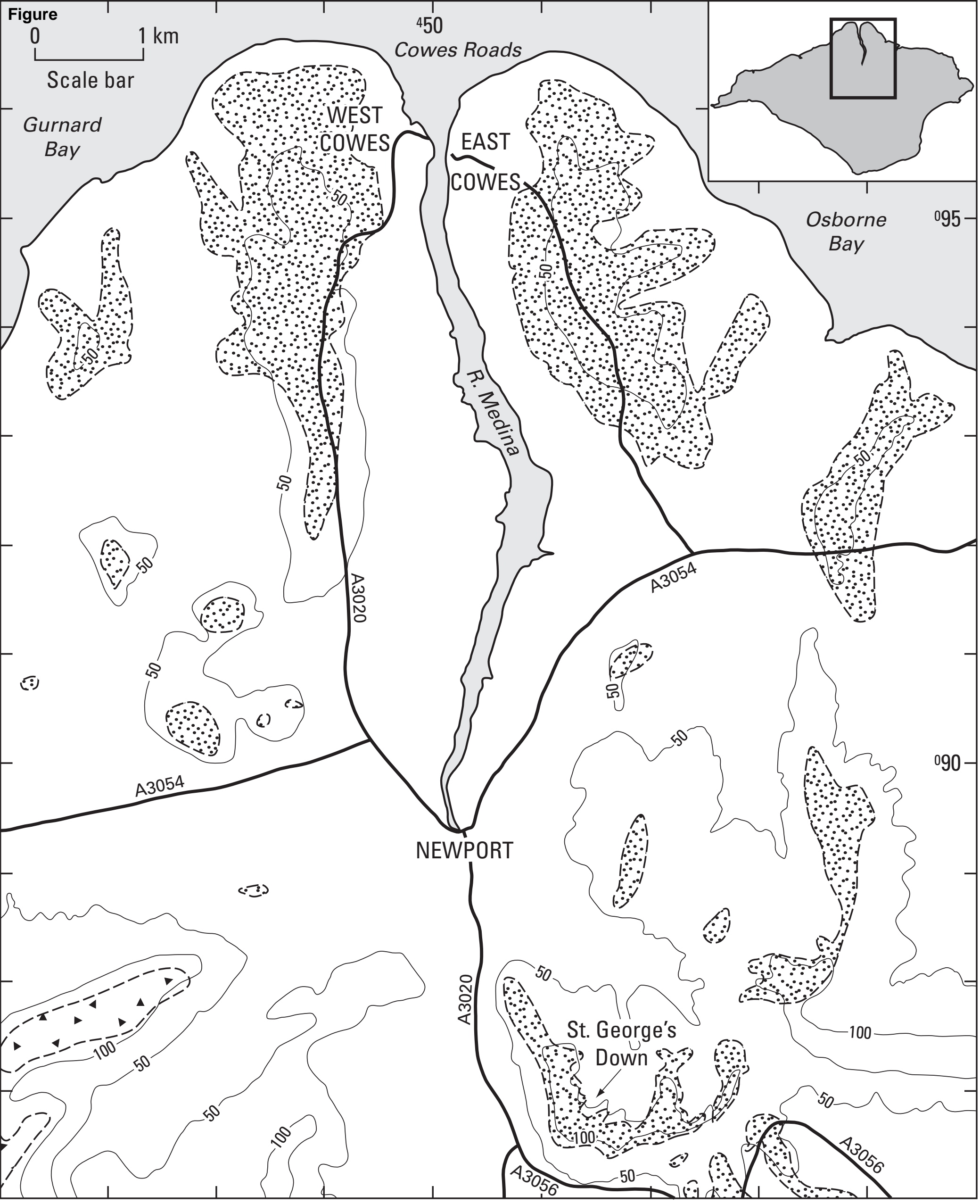

'Plateau gravel' 


\section{Figure}

Click here to download high resolution image

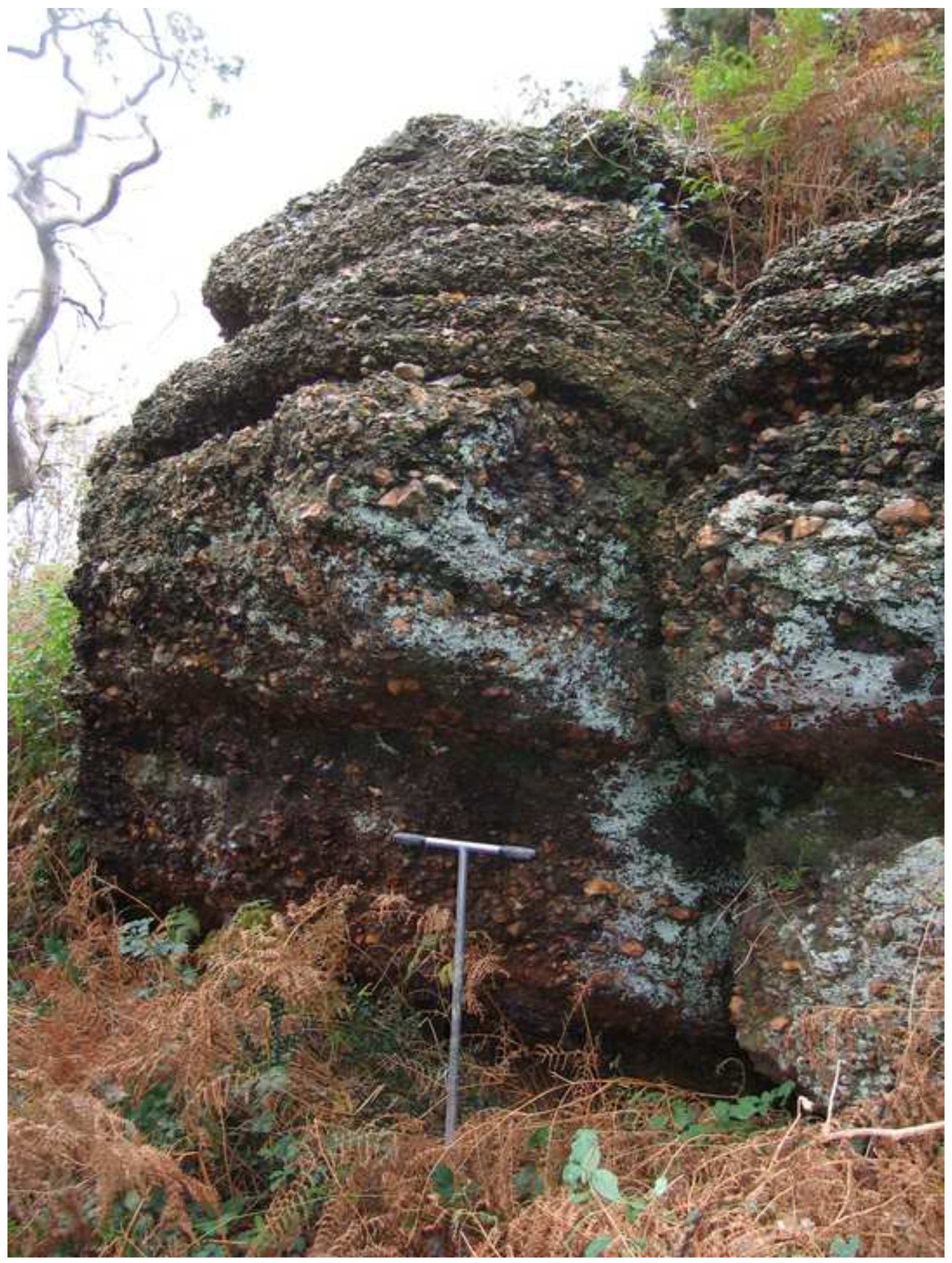


Click here to download high resolution image

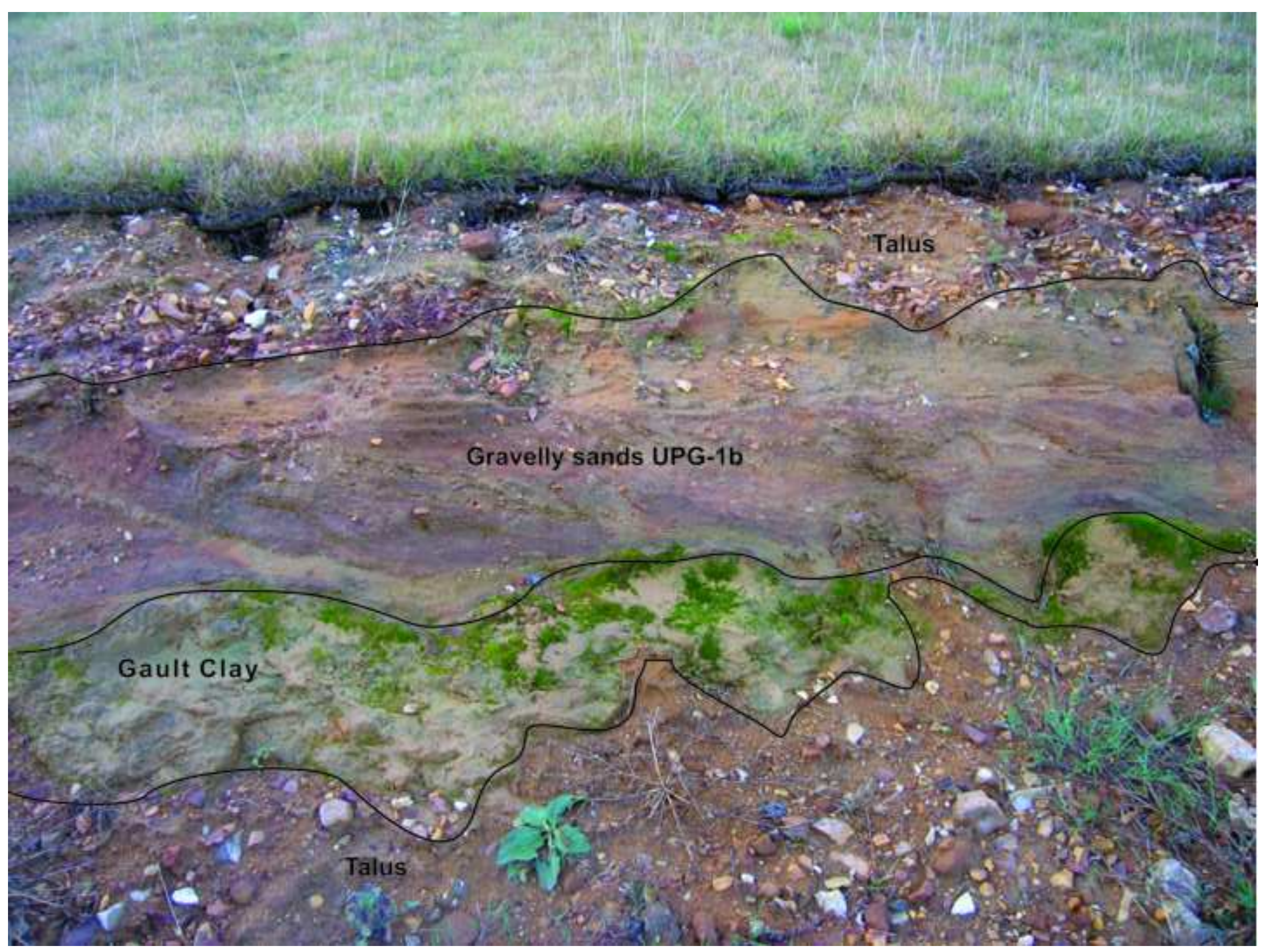




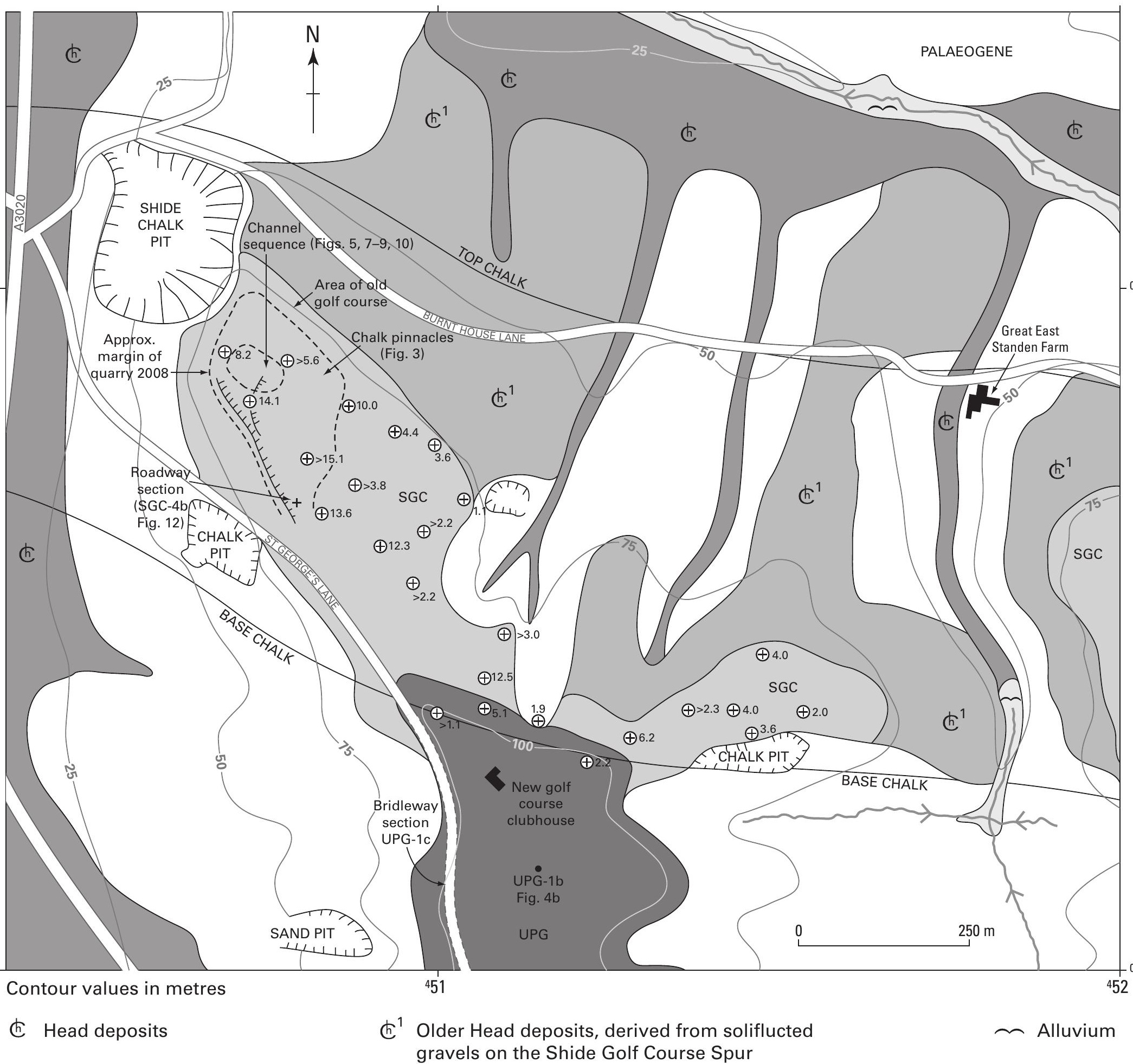


W

SZ 50758782
Quarry section May 2008

Laminated channel fill (May 2008)

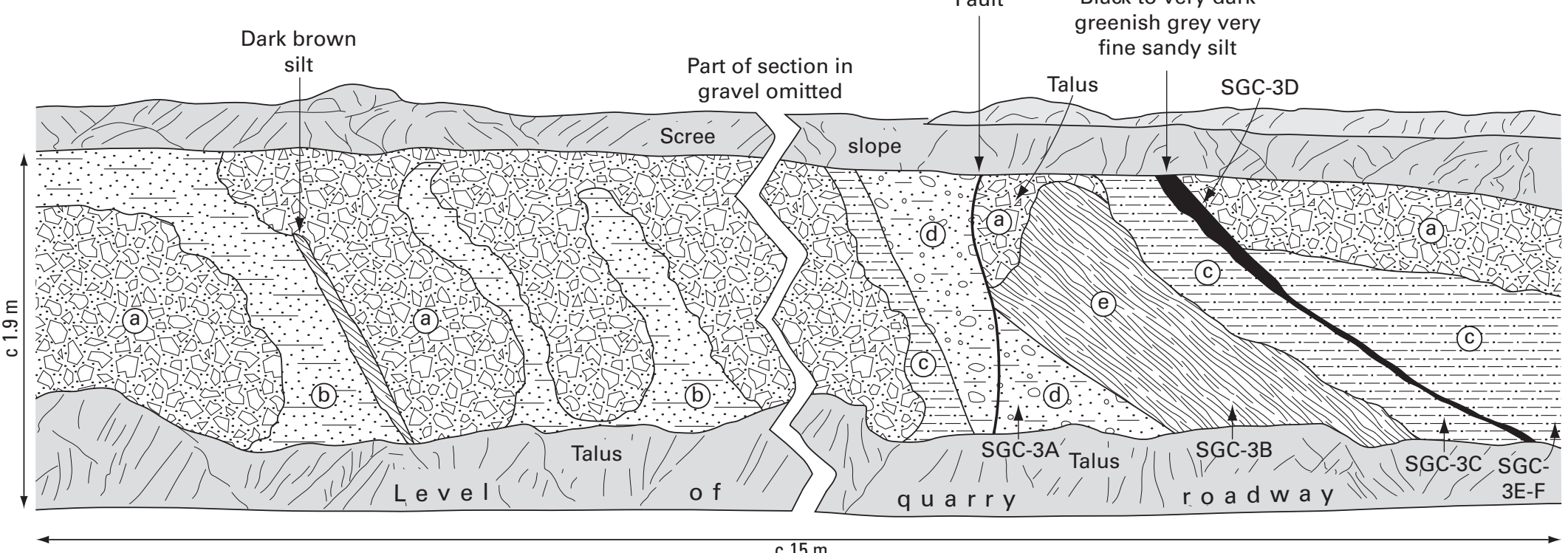

c $15 \mathrm{~m}$

Fine- to coarse-grained cobble gravel, consisting of angular to sub-rounded flint with rare sandstone, ironstone and quartz pebbles, set in a silty, clayey, yellow-orange-brown, fine- to medium-grained quartz sand. Rare chalk grains.

b Silty clayey sand to very sandy clayey silt. Generally fine- to medium-grained quartz sand and some rare coarse-grained angular flint and rounded quartz.

C Very fine-grained laminated sandy silt with rare flint clasts. Reddish to pink with pale grey rootlet traces or burrows perpendicular to laminae surfaces.

d Red / pink and grey - streaked silt with granule and fine gravel grade angular flints. Sandy throughout.

e Finely bedded to laminated grey very fine sandy clayey silt with thin red laminae. 
Click here to download high resolution image

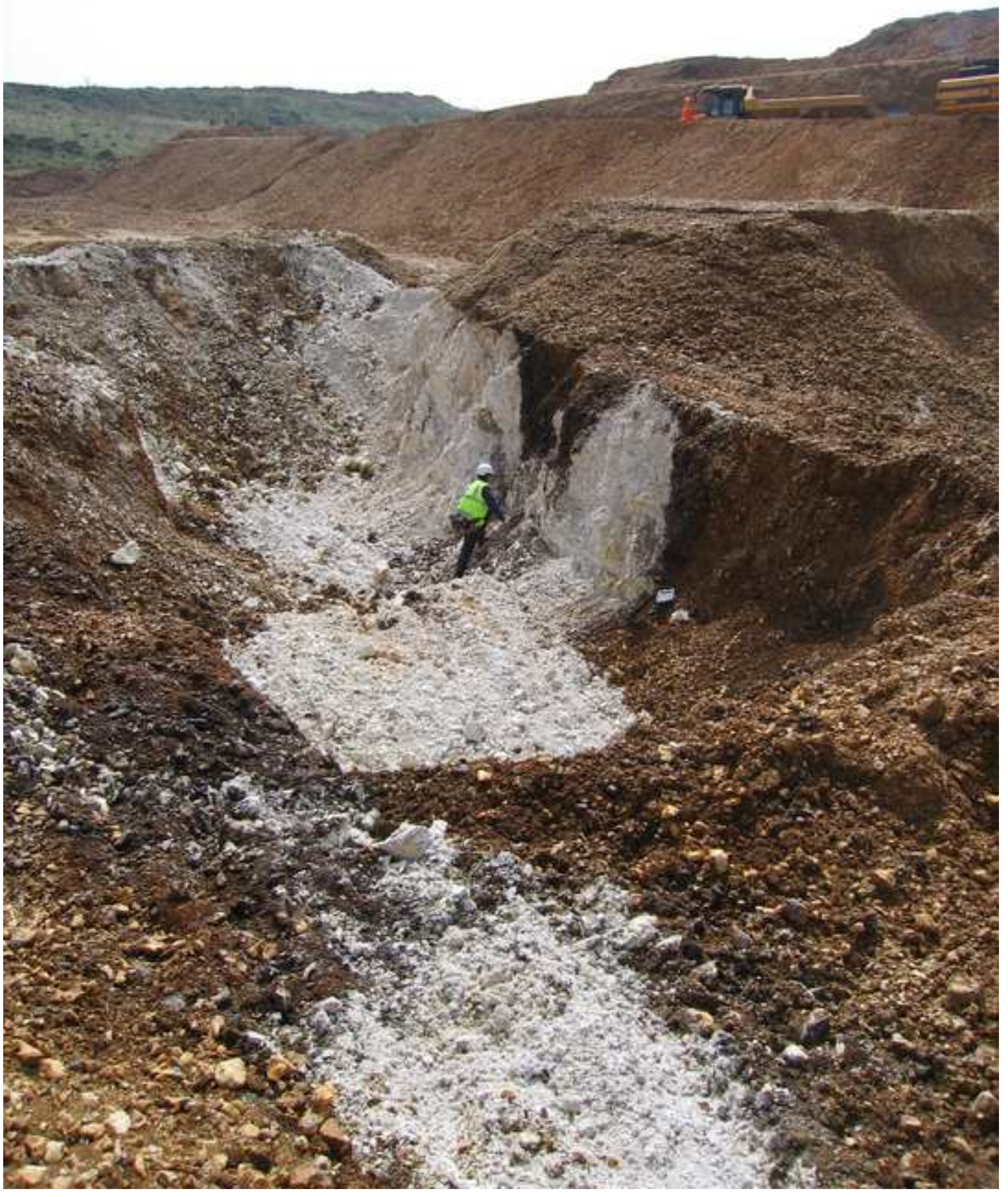




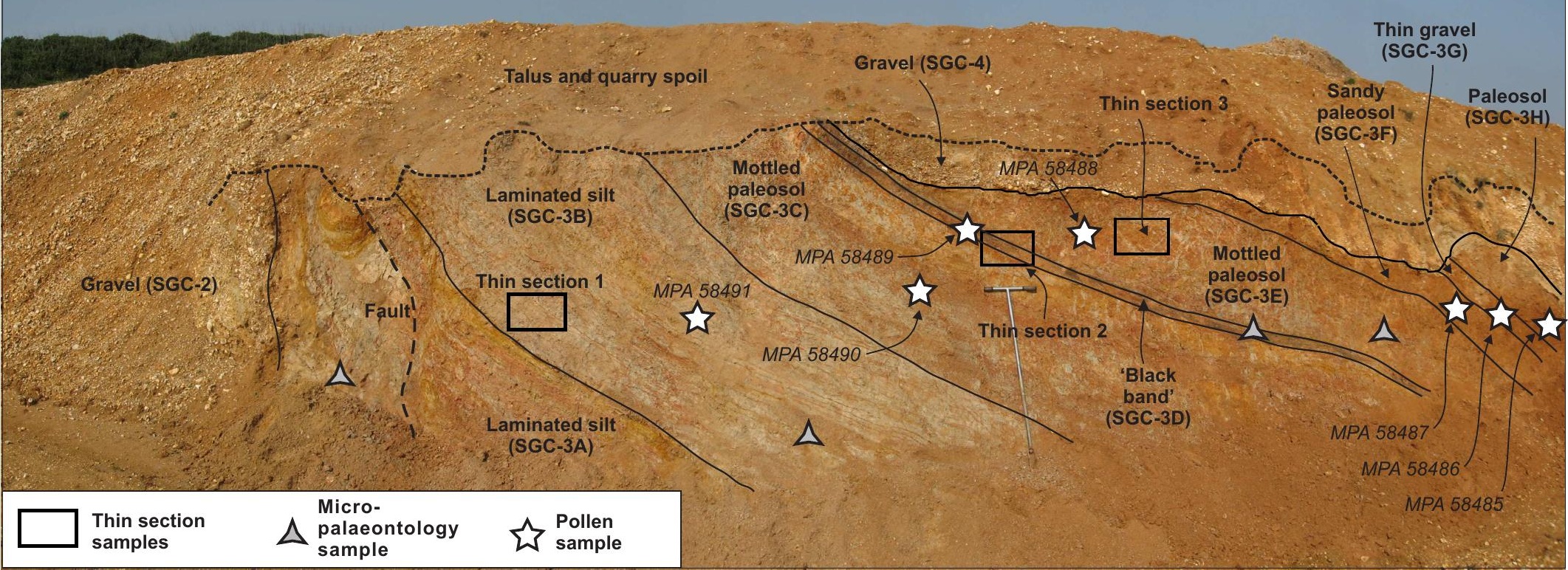


Click here to download high resolution image

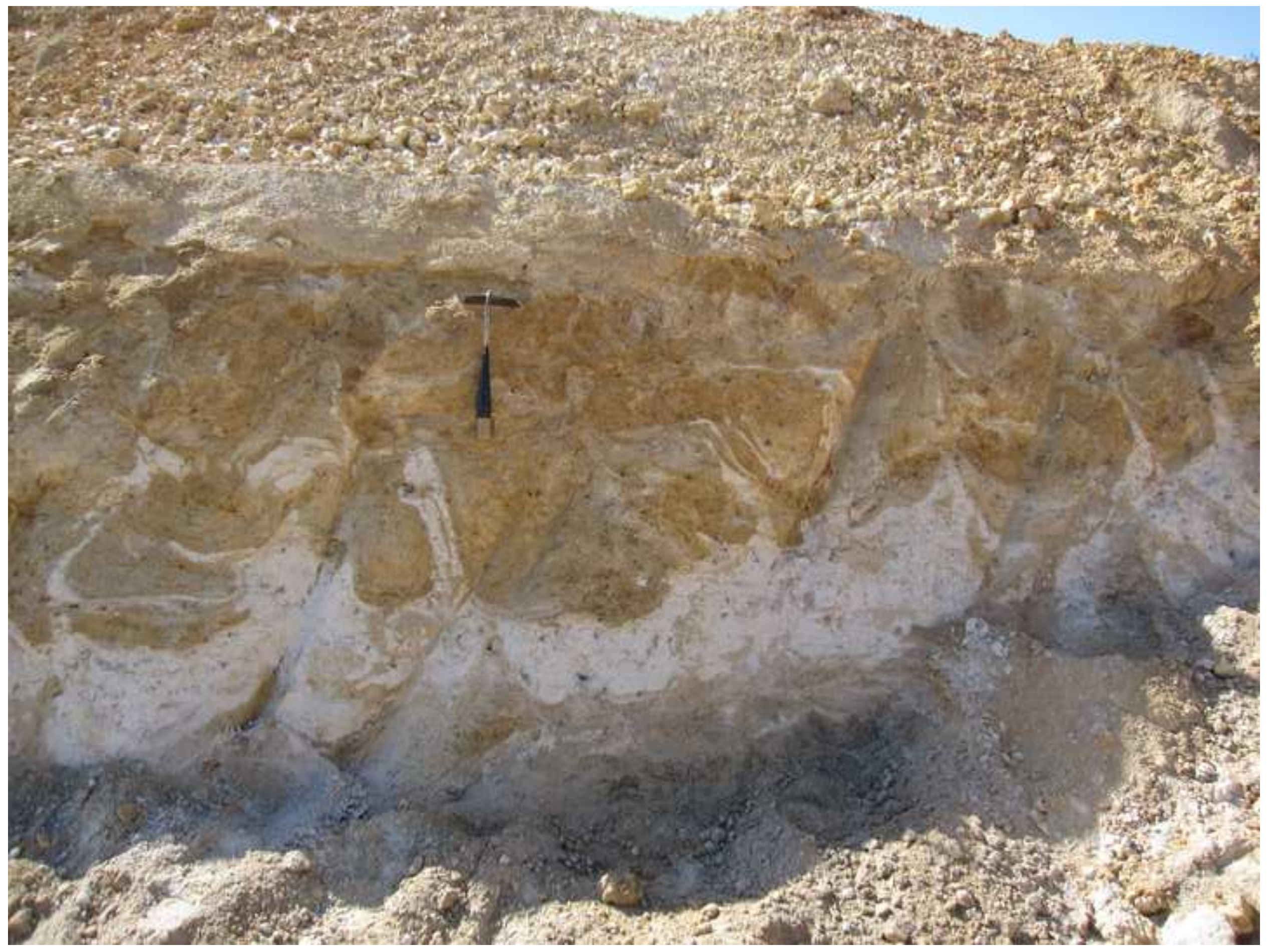




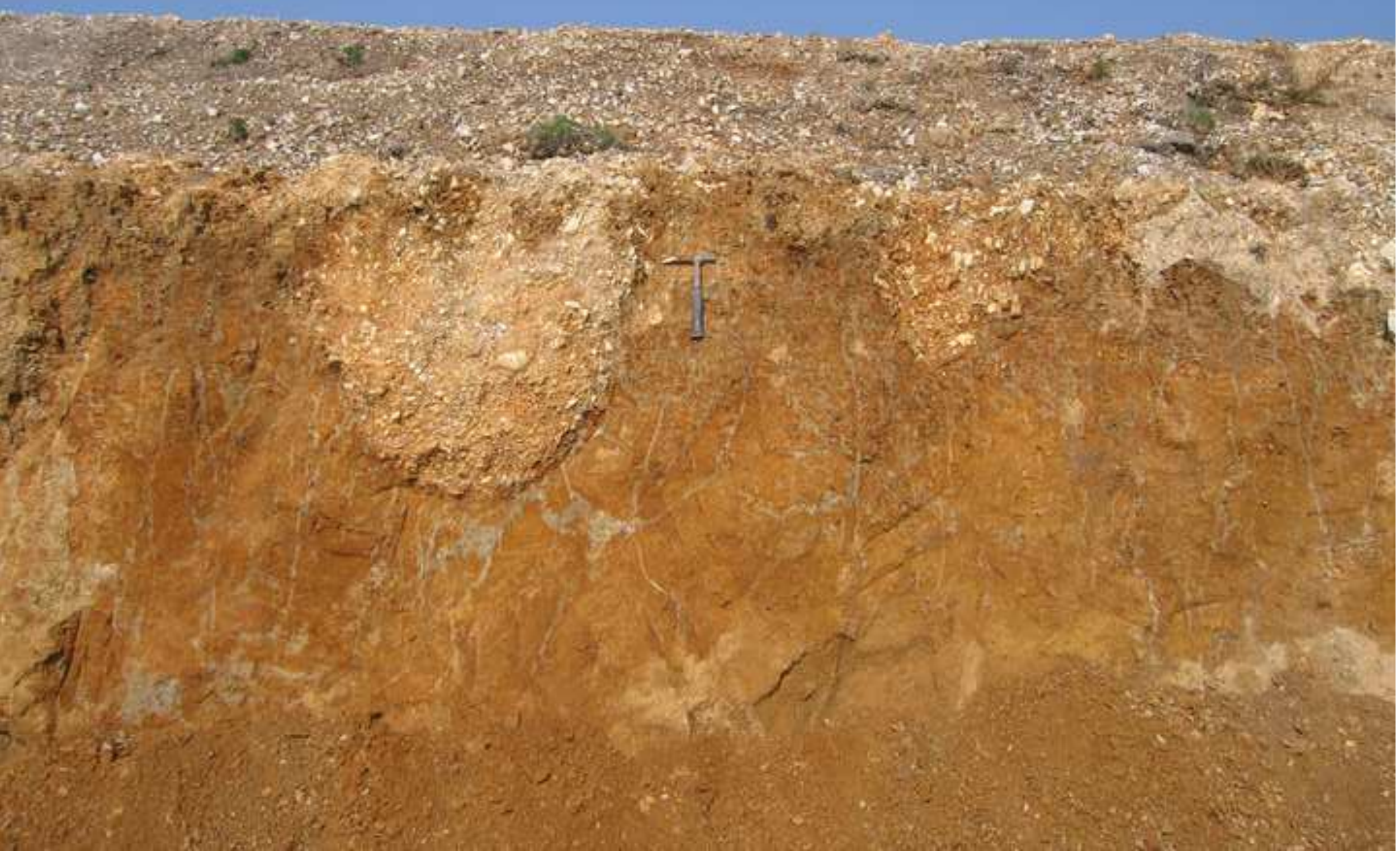



(SGC-4b)

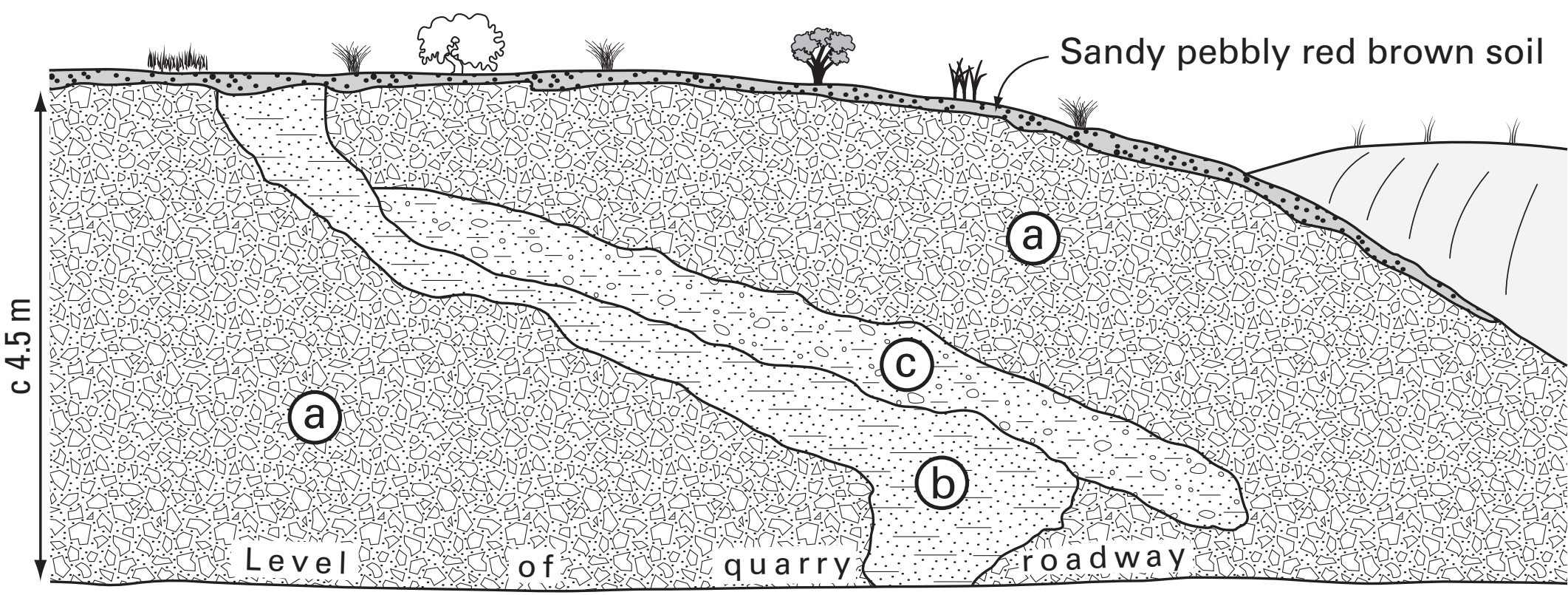
a Coarse gravel with cobble and fine angular to subangular flint and chert gravel, set in a matrix of very silty-clayey, fine- to medium grained, occasionally coarse sand. The gravel clasts are predominantly flint and Upper Greensand chert with some sandstone and rare fine quartz and ironstone. The sand is mainly fine- to medium-grained quartz sand.
b Pale grey, mottled orange, very fine-grained sandy silty clay
C Fine gravel with some patches of coarse gravel in an orange fine- to medium-grained, occasionally coarse grained, clayey sand matrix. 

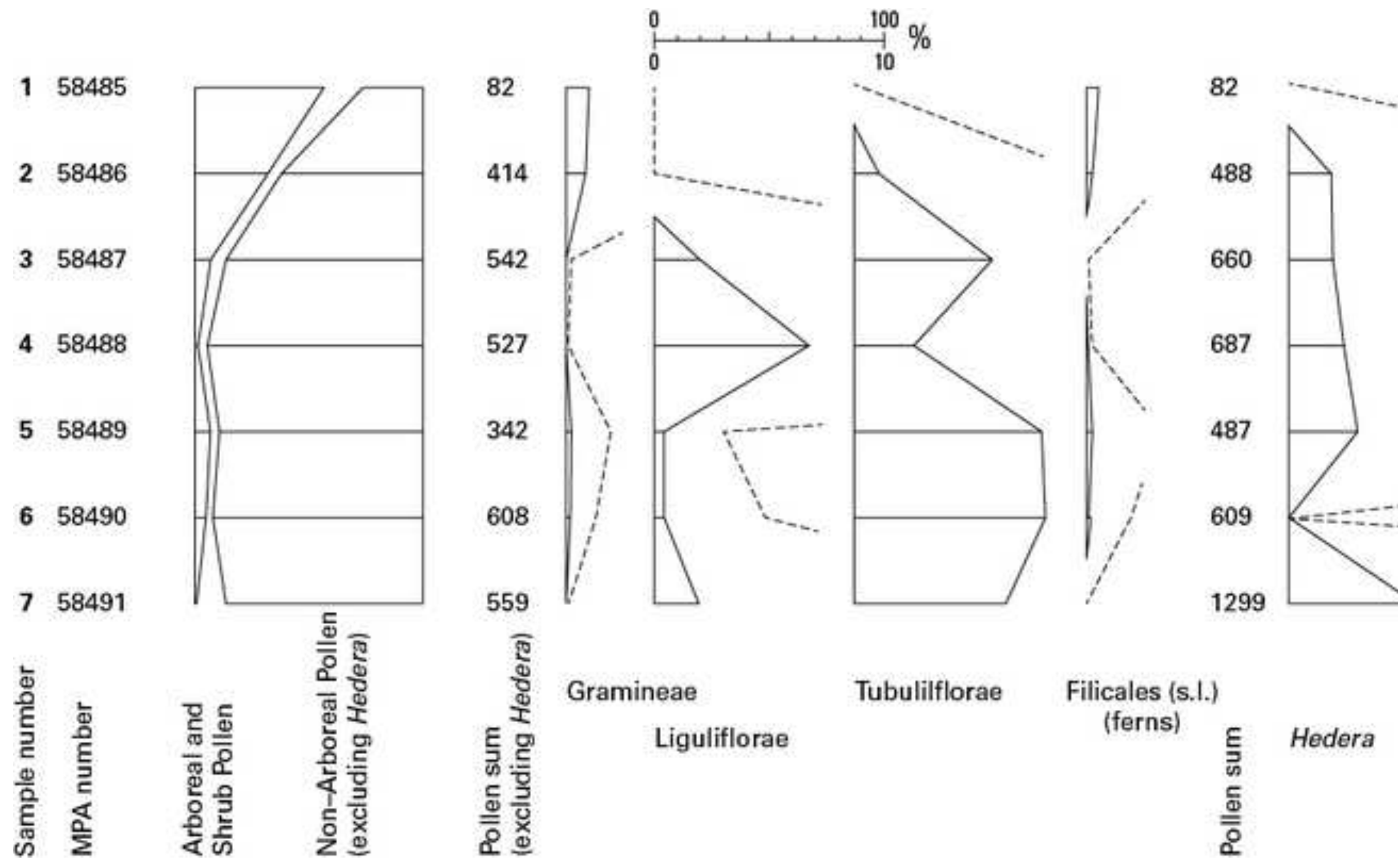

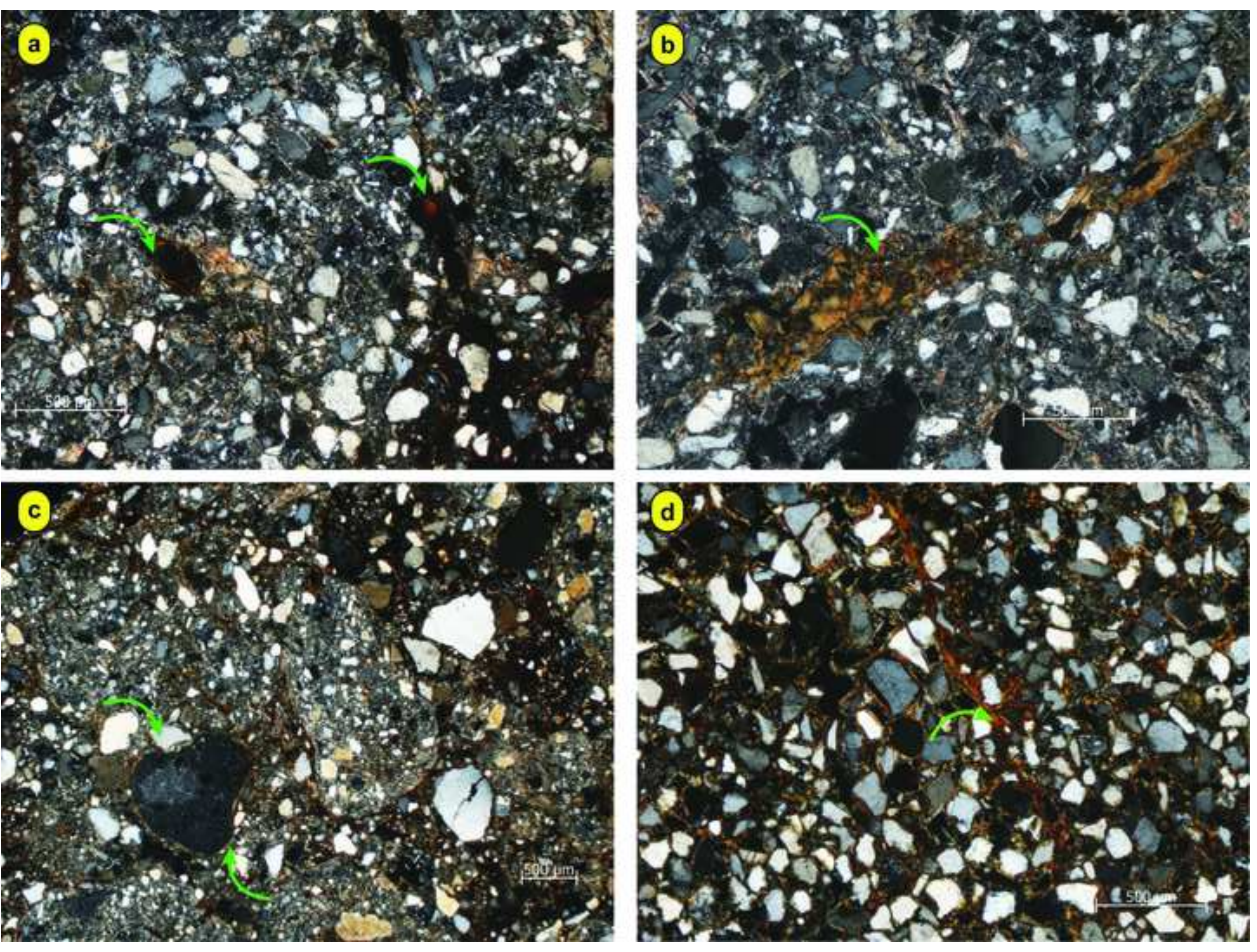